\title{
Enforcement of Labor Regulation, Informal Labor, and Firm Performance
}

\author{
Rita Almeida* \\ World Bank \\ Pedro Carneiro \\ University College London, Institute for Fiscal Studies \\ and Center for Microdata Methods and Practice
}

\begin{abstract}
This paper investigates how enforcement of labor regulation affects the firm's use of informal employment and its impact on firm performance. Using firm level data on informal employment and firm performance, and administrative data on enforcement of regulation at the city level, we show that in areas where law enforcement is stricter firms employ a smaller amount of informal employment. Furthermore, by reducing the firm's access to unregulated labor, stricter enforcement also decreases average wages, productivity, and investment. Our results are robust to several specification changes, and to instrumenting enforcement with 1) measures of access of labor inspectors to firms and 2) measures of general law enforcement in the area where the firm is located.
\end{abstract}

Keywords: Informal Sector, LaborMarket Regulation, Labor Demand, Flexibility, Productivity. JEL Classification codes: J3, J6, O17.

World Bank Policy Research Working Paper 3756, October 2005

The Policy Research Working Paper Series disseminates the findings of work in progress to encourage the exchange of ideas about development issues. An objective of the series is to get the findings out quickly, even if the presentations are less than fully polished. The papers carry the names of the authors and should be cited accordingly. The findings, interpretations, and conclusions expressed in this paper are entirely those of the authors. They do not necessarily represent the view of the World Bank, its Executive Directors, or the countries they represent. Policy Research Working Papers are available online at http://econ.worldbank.org.

*Corresponding author: Rita Almeida (ralmeida@worldbank.org). We thank the Brazilian Ministry of Labor for providing us the data on enforcement of labor regulation that we use in our paper and important information about the process of enforcement, especially Edgar Brandao, Sandra Brandao and Marcelo Campos. We thank George Clarke, Saul Estrin, Ana Fernandes, Mary Hallward-Driemeier, John Haltiwanger, Jennifer Hunt, Sara Lemos, Adriana Kugler, Stefano Scarpetta, Luis Serven, Rodrigo Soares and participants in several seminars for valuable suggestions. Carneiro thanks the hospitality of the Poverty Unit of the World Bank Research Group. 


\section{Introduction}

Throughout the world laws and regulations constrain the activity of economic agents and have substantial impact on the economic performance of different countries. Economic, social and political reasons are used to justify them, although very rarely any empirical evidence exists to back these up. However, the degree of compliance with regulation is likely to be as important for its impact as the details of the particular rule being enforced, although it is usually not explicitly considered. Economists study both the effect of regulation on social and economic outcomes (e.g., Heckman and Pages, 2003, Besley and Burgess, 2003), and the effect of enforcement on compliance with regulation (e.g., Levitt, 1997, 2004) in a variety of settings, but the two problems are not analyzed together. These two issues can and should be studied simultaneously: if variation in enforcement causes changes in compliance, then it will also have an effect on economic performance because the degree with which a given law is applied will vary.

In this paper we look to labor markets in Brazil and we examine two important issues on which our current empirical knowledge is quite limited: 1) what is the impact of enforcement on the employment of informal labor?; 2) what is the impact of increased labor flexibility on firm performance and total employment? In particular, we analyze how labor inspections and fines affect the demand for informal (illegal) labor by firms, and how access to informal (flexible) labor affects firm performance. Our empirical work integrates these two problems using insights from the literature on regulation, informality, crime and labor demand. ${ }^{1}$

Our work focuses on Brazil because it has one of the most regulated labor markets in the world (e.g., Botero, Djankov, La Porta, Lopez-de-Silanes and Shleifer, 2003). ${ }^{2}$ Furthermore, enforcement of the law is apparently weak since approximately $40 \%$ of total employment is

\footnotetext{
${ }^{1}$ We do not explicitly examine the damage illegal behavior inflicts on institutions and social protection. However, on the latter point the available evidence is not clear. Even though labor market institutions are usually used to explain differences in inequality across developed countries (e.g., Blau and Khan, 1996), it has been repeatedly shown that regulation can actually be detrimental to poverty and inequality in developing countries (e.g., Besley and Burgess, 2003, and the essays in Heckman and Pages, 2003).

${ }^{2}$ According to the Doing Business data set collected by the World Bank, Brazil has the third strictest labor regulation in the world. Labor market regulations changed significantly in 1988 with the new constitution, increasing the degree of worker's protection. A brief description of the current state of labor market regulation in Brazil is presented in table A1.
} 
in the informal sector. Even though labor regulation is the same in all Brazilian states, its enforcement is highly decentralized. This generates considerable variation in the degree of government monitoring faced by firms in different areas (which can be explored econometrically). Finally, there are three good sources of data which we combine in our study. First, we use a firm level dataset collected by the World Bank with standard information on investment, employment, sales and value added, but with unique information on the employment of informal workers (and other types of illegal behavior of firms). Second, from administrative data from the Ministry of Labor we construct measures of the enforcement of labor regulation at the local level. Third, we use information on the economic and demographic characteristics of all the cities where the firms in our sample are located collected by two Brazilian statistical and research institutes.

We explore the within country variation in the enforcement of regulation to analyze how it affects the firm's employment of informal workers and the firm's performance. We argue that the main channel by which enforcement of regulation affects firm performance is by reducing the firm's access to unregulated and flexible labor. However, enforcement can vary across locations for several reasons, and not all of them can be considered exogenous in our empirical work. Therefore we control for an extensive set of firm and local level variables which are likely to be important determinants of informal behavior, firm performance and enforcement. In addition, we use a set of instrumental variables for enforcement which are measures of access of labor inspectors to the firms in their region, and a proxy for general law enforcement in the region.

We find that increased enforcement in the area where firms are located leads to a substantial reduction in the amount of the informal workers they employ. We also find that it leads to a large decreases in value added per worker, sales per worker, net wages and capital per worker. We do not find any evidence that stricter enforcement changes total employment (suggesting that firms simply substitute informal for formal workers). The elasticities of informal employment and labor productivity with respect to enforcement are approximately -0.12 and -0.1 (respectively). These estimates imply that an increase in labor flexibility due to an increase in informal employment by 1 percentage point increases productivity in $3.5 \%$. 
Our paper contributes and relates to three different strands of literature. First we relate to the literature on the economics of crime. Even though the incentives of criminals have been studied extensively (e.g., Becker, 1962, and Levitt, 2004) very little is known empirically about the firm's incentives to hire informal workers and how enforcement can reduce illegal behavior. Our estimates of the elasticity of crime with respect to enforcement are similar in magnitude to those found in other contexts by Levitt (1998) and Bar-Ilan and Sacerdote (2004).

Second, our paper is related with the literature that analyses the consequences of restrictive labor market regulations on economic efficiency. A large part of this literature uses cross country variation to identify the effects of more restrictive labor regulation on aggregate outcomes (e.g., Nickell and Layard, 2000, Botero, Djankov, La Porta, Lopez-de-Silanes and Shleifer, 2003, Heckman and Pages, 2003). The evidence from this literature suggest that stringent labor marker regulation hamper productivity growth. ${ }^{3}$ More closely related to our work are Holmes (1998) and Besley and Burgess (2003). Holmes (1998) exlores variation across states in the US and shows that states which enacted pro-business right-to-work laws had increases in manufacturing activity. Besley and Burgess (2003) also find important effects of labor regulation on output, employment, investment and productivity in Indian manufacturing. Like us, both papers explore regional variation within a country. However, our analysis focus on differences in the enforcement of the labor regulation, not on differences in the regulation itself. Moreover, we use firm level outcomes instead of regional data.

Finally our work also relates to the literature on informality. The available cross country studies of the determinants of the informal economy provide several insights to the study of informality. Direct and indirect tax rates as well as stringent labor regulations are found to be strong determinants of the variation in the size of the informal sector across countries, although the enforcement of regulation can play an even more important role (e.g., Loayza,

\footnotetext{
${ }^{3}$ Scarpetta and Tressel (2004) suggest that this effect happens through a reduction in the incentives for innovation and new technology adoption. Other papers focus on specific changes on labor regulations or social security payments (e.g. Heckman and Pages, 2003, Gruber, 1997, Kugler, 2001, or Kugler and Kugler, 2005).
} 
1997, Johnson, Kaufmann and Zoido-Lobaton, 1998a,b, Loayza, Oviedo and Serven, 2005). ${ }^{4}$ The modern micro literature on informal labor markets (e.g., Maloney, 2004) suggests that we should look at the formal and informal sectors in an integrated way (as opposed to a segmented view of the labor market) and emphasizes the role of the informal sector as a source of unregulated labor to firms. This is the basis of the economic reasoning underlying our work.

The paper is organized as follows. In section 2 we describe the Brazilian labor market, the enforcement of regulation in Brazil, and a simple model that guides our empirical work. Section 3 describes the data. In Section 4 we analyze the relationship between enforcement, informal employment and firm performance. In section 5 we present estimates of the importance of labor flexibility for firm productivity and wages. Section 6 concludes.

\section{Background}

The Brazilian labor market has a large number of unregistered workers. According to the Brazilian National Statistical Institute (IBGE), there were 36 million wage earners in the private sector in 1999, 40\% of which were informal workers. ${ }^{5}$ Brazil also has one of the most highly regulated labor markets in the world. ${ }^{6}$ In a recent paper Botero, Djankov, La Porta, Lopez-de-Silanes and Shleifer (2003) document that Brazil has the highest score in an index of strictness of employment law. Since we expect to find higher levels of non-compliance with the law in the presence of strict regulation (Loayza, Oviedo and Serven, 2005), it is not surprising that the level of labor informality in Brazil is so high. In this section we briefly

\footnotetext{
${ }^{4}$ Most of the cross country studies find that income tax and social security burden are important determinants of the informal economy. The larger is the difference between total cost of formal and informal labor, the greater the incentive to hire informal workers (e.g., Loayza, 1997 and Reinhard, Hofreither and Schneider, 1989). Loayza, Oviedo and Serven (2005) show that labor regulations are positively related to the size of the informal sector but that the strength and efficiency of government institutions are negatively related to it.

${ }^{5}$ Informal workers here include self-employed workers, non-paid workers and the employers and employees in small firms. In our empirical work we define informal workers those that do not have their labor contract registered in a work permit (we ignore self-employment).

${ }^{6}$ In the early 1980s informal workers only accounted for $30 \%$ of the workforce. During the 1990s, there was a large increase in informality following several market oriented reforms (like privatizations and trade liberalization) and the new federal constitution in 1988, which greatly reinforced job security regulation. Barros and Corseuil (2001) describe the current rules governing worker's rights and the organization of unions.
} 
describe the main features of labor regulation and its enforcement in Brazil. Then we briefly discuss how we expect regulation and enforcement to affect informal employment and firm performance.

\subsection{Labor Market Regulation and Enforcement in Brazil}

All employees in Brazil must have a work permit (carteira de trabalho) on which the employment history of the worker is registered. This permit officially entitles the worker to several wage and non-wage benefits paid for by the employer, such as retirement benefits, unemployment insurance, and severance payments through access to a special fund created for this purpose, the Fundo de Garantia por Tempo de Servico (FGTS). ${ }^{7}$ The law establishes that all employers must register new labor contracts in the employees' permit. The employer must also register the type of work contract, as well as all modifications to an existing contract (including changes in the wage rate or in the period of leave).

Employers face several costs when hiring formal workers (beyond their net wage) such as taxes and other indirect benefits (payments to the FGTS, 30 days of paid leave per year, previous notification in case of dismissal ${ }^{8}$ and maternity and paternity paid leave). In the case of informal hires most of these benefits are negotiated on a case-by-case basis between the employer and the employee. Moreover, unregistered workers do not have access to unemployment benefits and severance payment. Neri (2000) argues that firms comply with most of the worker's rights relative to minimum wages, hours of work and other employment

\footnotetext{
${ }^{7}$ The FGTS is a government administered fund that is accumulated while the worker is employed. The employer contributes monthly with $8 \%$ of the current wage. Therefore, the total amount in the fund in any given period is a function of the job tenure and the wage history of the worker. Unfairly dismissed workers have access to their entire fund, including all funds accumulated in previous jobs, plus $40 \%$ of the employer's cumulative contribution to the worker's FGTS. The fact that dismissals are the only way to obtain the FGTS and that, once dismissed, the worker immediately receives severance pay, provides strong incentives for workers to induce dismissals whenever they want to quit. On the other hand, firms tend to reduce dismissals when large dismissals penalties are at stake (in the case of high wage - high tenured workers). Large firing costs also imply that firms become selective in the hiring process and this tends to reduce dismissals. Barros, Corseuil and Foguel (1999) argue that firms and workers have incentive to collude to turn quits into dismissals. In this case, workers have access to the FGTS but firms do not have to go to court.

${ }^{8}$ In Brazil the notification period (i.e., period between the notice and actual dismissal) is approximately one month. During this period, workers are given two hours per day to search for a new job. During this period the worker's productivity is likely to fall significantly, but the firm still has to pay the full wage.
} 
practices, even for informal workers. Therefore, the major incentive for firms to hire informally is to avoid mandatory payments to the government (e.g., social security payments, FGTS contributions) which in Brazil can amount to $100 \%$ of the net wage paid to the worker (effectively doubling the cost of labor).

Compliance with labor regulation in Brazil is enforced by the Ministry of Labor. Given the size of the country, enforcement is first decentralized at the state level and then decentralized further at a more local level, which in this paper we call subregion (a detailed description of the structure of this bureaucracy is provided in the data appendix). Each subregion includes several cities (municipios). The offices of the Ministry of Labor in the state and the subregion are called delegacia and subdelegacia, respectively. Labor inspectors are affiliated with a particular subdelegacia and visit firms within the corresponding subregion, assessing their compliance with several dimensions of labor law (such as worker registration, minimum wages, FGTS, working hours or leave benefits). There is an effort to apply an homogeneous criteria in the enforcement of the labor regulation throughout the country, but in practice this is very difficult to achieve. ${ }^{9}$ Enforcement is likely not to be uniform across subregions because Brazil covers a very large and diverse geographical area, the number of inspectors involved is also large and probably very heterogeneous in their ability and honesty (which is important in the case inspectors are offered bribes). ${ }^{10}$

When a worker is found not to be registered, or if there are changes in the wage or hours of work of the employees that were not included in the work permit, the inspector notifies the firm of its violation. After receiving a notification, the firm has 10 days to present evidence in its defense. Because it is the firm's responsibility to register the worker's contract, once notified it is very difficult to prove its innocence. ${ }^{11}$ Therefore, even though a notification does not imply a fine, in the particular case of the registration of workers, it almost always does. A firm is fined 300 Reais (USD \$130) for each worker that is found unregistered during

\footnotetext{
${ }^{9}$ The Ministry of Labor provides training continuously to labor inspectors: all inspectors have a common implementation manual and work with a similar software. At the end of 2002, there was a total of 2341 labor inspectors in Brazil.

${ }^{10} \mathrm{Up}$ to $50 \%$ of the inspectors' wage is tied to their performance giving them a strong incentive to penalize all the infractions they can find. However, there is still an incentive to collect bribes.

${ }^{11}$ Exceptions include the cases where a third party (such as a union) is responsable for the registration.
} 
an inspection (which can occur more than once a year) but the fine is reduced by $50 \%$ if the firm pays within 10 days of the date of notification ${ }^{12}$ (other types of violations of the labor code are also punishable with fines, although we do not describe them here).

In summary, Brazil has very restrictive labor market regulation, which provides strong incentives for noncompliance on the part of firms and workers. Since law enforcement is imperfect there is a large amount of informal employment. Furthermore, enforcement is highly decentralized which results in substantial variation in enforcement across areas.

\subsection{Informal Employment and Economic Performance: Theoretical Considera- tions}

In this paper we examine how variation in the enforcement of the law influences illegal behavior on the part of firms and, as a result, how it affects their productivity. Underlying our empirical work is a simple model that relates enforcement of labor regulation, the demand for informal labor and firm productivity. In this section we briefly describe such a model and its implications for our empirical work.

We consider a firm choosing simultaneously two types of labor (formal and informal), capital and the technology of production. Firms can choose different types of technology depending on the prices of different inputs. Technology, capital and formal labor are quasi fixed inputs, while informal labor can be flexibly adjusted every period. The additional flexibility of informal labor is due, for example, to lower hiring and firing costs (Oi, 1962), or to the lack of regulation in working hours. We assume there are no other differences between these two types of workers (for example, differences in education or other measures of skill). There is no distinction between formal and informal firms, but only between formal and informal workers (our assumption is that all firms are fully registered, although part or all of their workers may not be legally registered).

We consider informal workers to be unregulated workers who coexist with formal workers in a single labor market, as opposed to assuming segmented labor markets. ${ }^{13}$ However,

\footnotetext{
${ }^{12}$ In the firm level data we use in the paper the number of inspections in a firm in 2001 varies between zero and 60. The median number of annual labor inspections is 1 and the mean is 1.33.

${ }^{13}$ Maloney (2004) (and others) argue for a unified labor market approach as opposed to a dual view of the labor market.
} 
there are important differences in the monetary cost of these two types of labor. When hiring informal workers firms can forego the payment of taxes and mandatory social security contributions but, because they violate the law, they face potential punishment from labor authorities.

The government enforces employment registration imperfectly because enforcement is costly, and the degree of enforcement varies exogenously across firms (either over time, or across different regions). Firms which hire informal workers face the prospect of a fine (proportional to the amount of hired informal labor) with some probability, which is a function of the characteristics of the firm and its efforts to avoid regulation. For example large firms, or firms with a large percentage of public capital are more visible to labor authorities (e.g., Loayza, 1997). Therefore, firms hiring informal workers are likely to be small. $^{14}$

For simplicity, we do not distinguish the role of the probability of being caught from the size of the fine. We assume that firms face a cost of hiring informal workers which varies with the degree of enforcement of the regulation. As enforcement increases so does this cost, and therefore the amount of informal workers hired decreases. Furthermore, when the cost of access to unregulated workers increases (due to increased enforcement) the flexibility of the firm's labor force decreases, and the price of labor increases.

Firms may respond to increased enforcement in several ways. For example, they may choose capital intensive technologies when enforcement is strict (avoiding large labor costs) and labor intensive technologies when enforcement is loose (Loayza, 1997). Alternatively, whenever enforcement is loose, firms can choose technologies that are more productive when labor is flexible, and these can be either labor intensive or capital intensive. For example, Besley and Burgess (2003) find that pro-worker labor regulation in India (which makes labor more expensive) leads to lower investment. They also find that it leads to lower labor productivity.

In principle we would expect total employment to increase when enforcement is less strict

\footnotetext{
${ }^{14}$ We do not consider bribes to labor inspectors although they could be easily incorporated as a form of fine. Stigma effects due to bad publicity to the firm can also be incorporated as a form of fine.
} 
(although this depends in part on the choice of technology). In fact, it is often argued that an important benefit of deregulation is increased employment: workers forego job security for higher employment. However, employment effects can be quantitatively small. ${ }^{15}$ In fact, when labor regulation became more restrictive in Brazil there were only small effects on employment, as reported by Barros and Corseuil (2001). In the presence of reduced enforcement, if all firms substitute formal by informal workers then there will be no change in employment. Still, there could exist large changes in firm performance, especially if the substitution of formal by informal workers leads to a reduction in the firm's labor costs.

Net wages may increase if the firm is more productive, but gross labor costs will probably fall since the firm is paying less to social security. Net average wages may also increase if informal workers earn more than formal workers (keeping worker characteristics fixed). This will be the case if firms share with informal workers the savings in social security payments they get by hiring them. ${ }^{16}$ In the empirical work that follows we examine how enforcement affects the firm's employment of informal workers, and how it subsequently affects total employment, wages, productivity and investment.

\section{Data}

Descriptive statistics of the main variables that we use in the analysis are reported in appendix table A1. The source of firm level data is the Investment Climate survey collected by the World Bank. The survey is representative of a set of manufacturing sectors that together account for $75 \%$ of the manufacturing value added and employment in 2002 (details of the survey are given in the data appendix). In the collection of this dataset the World Bank worked with a private survey firm. Given the detail and the sensitive nature of some

\footnotetext{
${ }^{15}$ For example, if firms change their technology then the demand for labor schedule changes and employment can increase or decrease, depending on whether the new technology is more or less labor intensive. Furthermore, assume that the wage of informal workers plus the potential penalty cost from hiring them is approximately equal to the net wage of formal workers plus social security costs, so that total labor costs with each type of worker are the same. Then, instead of a change in employment, firms may just choose to substitute formal for informal workers.

${ }^{16}$ This is usually labeled as "fiscal kink" (or cunha fiscal). Given that the total labor costs of formal workers greatly exceed their net wage, there is a strong incentive for firms to hire informally and for workers to be hired informally, if the savings from such an exercise (unpaid social security benefits) can be shared between both parties.
} 
of the questions the survey was designed to be answered by the firm's manager. The typical observation is based on a three-hour interview which often implied two visits to the firm to accommodate the manager's time schedule. This resulted in a sample of 1641 firms with information on several characteristics of the firm, such as total employment, sales, value added, labor costs, capital stock, share of high educated workers, share of workers with training, age of the firm and share of foreign and public ownership. These firms are located across 306 cities (77 subregions) in Brazil. The survey also collects information on the number of labor inspections in each firm and whether it had to pay any fines or bribes. Of particular interest to us is information about the degree of labor informality in the firm. Even though every firm in our sample is legally registered there are some firms that employ informal workers.

The survey collects indirect information on the use of informal labor through the following question: "Given the constraints to hire workers and the additional costs that it entails, in your opinion, what is the percentage of the permanent employment that is informal/unregistered in a typical firm of this size and in this industry?". ${ }^{17}$ The question is phrased indirectly to avoid implicating the respondent in any wrongdoing. Throughout the paper we will assume the answer to be a good indicator of the firm's own degree of labor informality. Still, many of our empirical results relating enforcement and firm performance do not depend on the use of this variable.

Even though similar questions have been used successfully in the study of corruption (Svensson, 2003), there can be doubts about the extent to which the answer to this question measures the degree of informality of the respondent firm. Several arguments support our use of this variable, although none of them is definitive. First, firms are also asked to judge to what degree similar firms generally comply with labor law. We find that $41 \%$ of the firms simultaneously claim that their competitors comply perfectly with labor law and state that similar firms hire a positive percentage of informal workers. Such responses would be inconsistent unless firms that were similar to the respondent firm were not its major competitors (which is unlikely), or if the answer to the question on informal employment

\footnotetext{
${ }^{17}$ The survey also collects information on the share of temporary workers. However, since in our data temporary employment is negligible we focus only on permanent workers.
} 
really corresponded to the degree of informality of the respondent and not of a group of similar firms (which we take to be the case). Second, firms also report their labor costs, inclusive of a variety of taxes and social security payments. We observe that firms employing informal workers pay on average $61 \%$ lower taxes and social security payments per employee than those only hiring legal workers (according to our definition). Even after controlling for industry, location and average net wage in the firm, the formal-informal differential in social security payments and taxes is still $17 \%$. If the answer to the question above were not related to the percentage of informal workers employed by the respondent firm this relationship would probably not take this form so clearly. Third, firms are asked whether they would like to change their workforce if they had no hiring or firing costs. We find that those firms that report that they would like to change their workforce (either increase or decrease) are 20 percentage points more likely to report using informal labor. ${ }^{18}$ In other words, under our interpretation, firms facing stronger labor market constraints are more likely to employ informal workers. Fourth, the manager of the firm is asked to rank the importance of different obstacles to the firm's growth. In particular, managers have to rank the following barriers to business (among others) from 0 (no obstacle) to 4 (severe obstacle), among others: telecommunications, electricity, taxes, export regulations, labor regulations, corruption, crime, anti-competitive practices. We find that managers who report that labor regulations are a severe obstacle are more likely to report employment of informal workers. ${ }^{19}$

\footnotetext{
${ }^{18} 69 \%$ of the firms that say that they would like to change their workforce report a positive share of informal workers while only $49 \%$ of the firms that say they would like to remain with the same number of workers reports a positive share of informal workers.

${ }^{19}$ While $70 \%$ of the firms reporting that labor regulations as a severe obstacle report also labor informality, only $52 \%$ of the firms reporting that labor regulations are not an obstacle also report labor informality. However, both arguments 3 and 4 can be seen in reverse as well: it would be possible that firms who report that they would not like to change their workforce, or that they are not constrained by labor regulations, are precisely the ones with the highest amount of informal workers. Because they employ unregulated labor, they do not feel constrained. We also observe that approximately $10 \%$ of the firms do not provide answers for the informality question, but still report data for sales, capital and other inputs. The missing data raises questions relative to possible sample selection. To address this issue, we check whether firms with missing information also decline answering other questions that also would implicate them in wrongdoing. We find no evidence that firms avoid all wrongdoing questions. In particular, the survey asks an indirect question on the share of the total sales reported for tax purposes. About $70 \%$ of the firms that do not answer the question on labor informality, do answer the question on (indirect) tax evasion. Furthermore, firms that do not report data on informal workers are not statistically different from firms that report this information on a variety of dimensions (results available upon request). This evidence suggests that our sample is not
} 
Table 1 presents differences (across a variety of dimensions) between firms reporting a positive number of informal workers and firms reporting no use of such workers in our sample. The numbers in the table are the coefficients of a regression of different firm characteristics on a dummy variable that equals one if the firm reports using informal workers. Column (1) includes no other controls in the regression, while in column (2) we control for sector dummies and some regional characteristics. ${ }^{20}$ Approximately $65 \%$ of the firms report using some full time informal workers. For these firms, on average informal workers represent approximately $36 \%$ of the permanent workforce. These firms are on average younger and smaller in terms of total employment, physical capital, value added, and profits than those reporting no informal employment, they have a less educated workforce and are less likely to provide formal onthe-job formal training to their workers. They are also less likely to be foreign or state owned than fully legal firms, they tend to be concentrated in low skilled/labor intensive sectors (like clothing, shoes and wood products) and are less likely to work in chemicals, machinery and electronic products. ${ }^{21}$ Finally, firms employing informal workers report being more likely to pay bribes to labor officials (conditional on having been inspected) and are also more likely to underreport their sales for tax purposes than firms only hiring formal workers. ${ }^{22}$

We combine this firm level dataset with administrative data collected by the Ministry of Labor in 2002 on the number of regional offices that exist within each subregion ${ }^{23}$, number of inspected firms and the number of fines issued in each city (more details are given in the data appendix). We have information on the number of fines for different labor violations:

selective.

${ }^{20}$ We estimate an equation of the following form: $y_{j}=\beta D I_{j}+\gamma_{s} D_{s}+\epsilon_{j}$, where $y_{j}$ is the outcome of interest, $D I_{j}$ is a dummy variable that equals one if the firm reports using informal workers, $D_{s}$ are sector dummies and $Z_{r}$ are regional characteristics at the subregional level (total number of plants, population in 2002, $\log$ GDP in 1985, log population in 1991 and share of females).

${ }^{21}$ In our sample, these sectors are more likely to have a certificate of quality and are more likely to develop internally and /or jointly with costumers or suppliers new technology. These sectors also have more educated workers ( $40 \%$ of the workers have more than the bachelor degree vs $31 \%$ for the median in the sample) and higher wages.

${ }^{22}$ Firms that report using informal workers are also less likely to be exporters, to have quality certification of their products and to be licensed to use foreign technology than other firms not employing informal workers (results not reported in table 1 )

${ }^{23}$ The Ministry of Labor has regional offices in selected cities of each subregion. These offices are not decision units like the subdelegacias, but are designed for increasing the access of the public to the Ministry of Labor. 
registration fines, are fines related with the firm not registering the worker for a work permit, work load fines are fines related with the firm not complying with the official work load, wage fines are fines related with the firm not paying the minimum established by the law, hours of work fines are fines related with the firm not complying with the number of hours of work and the mandatory pauses, FGTS fines are fines related with the firm not making the mandatory discounts to the FGTS, transport subsidy fines are fines related with firm not paying the mandatory transport subsidy, and other fines are fines related with other mandatory obligations of the firm to their workers. We construct the total labor fines, as the sum of all these different fines. This data was aggregated from city to subregion level using information provided by the Ministry of Labor on all the cities that belong to each subdelegacia.

Finally, we also use information from two Brazilian statistical and research institutes (IPEA and IBGE). Data for population and for the total number of plants in 2002 is collected by the National Statistics Institute (IBGE). City level data for GDP (1985 and 2000), population (1991 and 2000), share of females (2000), geographical area (2000), transportation costs to the nearest capital city (1995), number of train stations in the city (1995) and homicide rate per 100000 inhabitants (2002) is collected by the Instituto de Pesquisa Economica Aplicada (IPEA). These variables are all observed at the city level and are aggregate to the level of the subregion.

\section{Enforcement of Regulation, Informal Labor and Firm Perfor- mance}

\subsection{Main Results}

In this section we examine the effect of enforcement of labor regulation on informal employment hired by the firm and on various firm outcomes. We estimate a set of relationships based on the following equation:

$$
Y_{j}=\alpha+\beta E_{j}+X_{j} \gamma+\varepsilon_{j}
$$


where $Y_{j}$ is the either the proportion of informal workers in firm $j$ 's total employment or a measure of firm performance (log value added per worker, log average wage, log sales per worker, log profit per worker, log capital per worker, log total employment and a dummy variable indicating use of advanced technologies), $E_{j}$ is enforcement of regulation faced by firm $j,{ }^{24} X_{j}$ is a vector of exogenous variables and $\varepsilon_{j}$ is a i.i.d. error term. ${ }^{25}$

As described in the previous section, enforcement of labor regulation in Brazil is decentralized at the level of the subdelegacia (subregion). This is the relevant level of variation for the enforcement data. We have administrative data on the number of labor inspections and on the number of fines issued in each subregion. We prefer to use labor fines rather than labor inspections as a measure of enforcement because we can discriminate fines by type of violation whereas we cannot discriminate inspections by type of offense (because inspections are general). In particular, we know the number of fines related specifically to irregularities that concern worker registration, registration fines. This is ultimately the enforcement measure that is most relevant for firms when deciding to evade (or not) the law and hire informally. Because some subregions are larger and have more firms than others, we normalize number of fines by number of firms in the subregion. ${ }^{26}$

A priori we expect $\beta$ to be negative when $Y_{j}$ is informal employment, but as we suggest in section (2.2) $\beta$ can be either negative or positive in the case of all other outcomes. We hope that our measure of enforcement is reasonably exogenous, and varies due to arbitrary differences in inspections across regions. However, for several reasons, it may happen that

\footnotetext{
${ }^{24}$ We use contemporaneous measures of enforcement instead of lagged measures of enforcement. This is because the current available data on enforcement is only for 2002 . We do not believe this affects the results in our paper.

${ }^{25}$ In the case where $Y_{j}$ is the proportion of informal workers hired by the firm, equation (4.1) is not an explicit labor demand equation but can be related to it in a partial equilibrium framework, where the prices of different inputs are kept fixed when enforcement varies across firms. However, a labor demand equation would have the number of informal workers employed by the firm on the left hand side instead of the proportion of informal workers in total employment. Our empirical results are similar when we use number of informal workers as our dependent variable in this regression (available on request). A similar reasoning applies when $Y_{j}$ is total employment in the firm or capital per worker. In the case where $Y_{j}$ corresponds to firm outcomes such as sales per worker or value added per worker, we do not estimate explicit production functions. However, the (reduced form) relationship we estimate between firm outcomes and enforcement of laws can be derived from a standard profit maximization problem with multiple types of labor which have different flexibility and different costs. It is also similar to the specification of Besley and Burgess (2003) and of other papers in the literature on labor regulation and economic performance.

${ }^{26}$ In practice, we will use total number of fines per 1000 firms in the subregion.
} 
$E_{j}$ is correlated with the error term in each of the equations we estimate, biasing simple OLS estimates of $\beta$. For example, subregions differ in characteristics (either at the firm or more aggregate level) that determine potential informality, i.e. the degree of informality that would exist if there were no enforcement. In some areas, firms are more prone to engage in informal behavior sand as a consequence enforcement will also be higher. The positive correlation between informality and enforcement is similar to the argument that "more crime leads to more police" (Levitt, 1997, 2002). This "reverse causality" is likely to cause the estimate of $\beta$ to be upward biased when the dependent variable is informal employment. It causes $\beta$ to be upward biased as well in the productivity regressions if in areas with more potential informality firms operate more efficiently (because they use unregulated labor). $\beta$ will be downward biased in productivity regressions if firms located in areas with more potential informality are also less productive (due to the type of firms they are, and industry they belong to).

It may also happen that larger firms with smaller amounts of informal workers locate in large cities where institutions are better and inspections are more rigorous, while smaller firms are located in less developed areas. This will induce a negative correlation between enforcement and informal behavior, leading to a downward bias in $\beta$ when $Y_{j}$ corresponds to informal employment. However, it is likely to lead to an upward bias in $\beta$ when $Y_{j}$ is firm productivity. Similarly, firms wishing to hire informal workers may sort into areas where enforcement is less strict, again causing bias in the estimate of $\beta$.

We would like to isolate variation in enforcement due to arbitrary severity of inspectors or costs of enforcement uncorrelated with potential informality, from variation in enforcement due to potential informality in the regions, endogenous sorting of firms or third factors correlated with both enforcement and informality. In order to do this we start by controlling for an extensive set of variables at the level of the firm, city and subregion. Our firm level controls are industry, age of the firm and share of foreign ownership. These variables are likely to be good indicators of the level of potential informality of the firm and are also likely to be fairly exogenous. ${ }^{27}$ Our subregion level controls include number of plants and

${ }^{27}$ We do not control for employment, capital intensity or productivity (when we do not use such variables 
number of individuals, share of females, log GDP in 1985 and log population in 1991 in the subregion. The latter two are included as a control for past per capita GDP in the area, which is likely to be a good predictor of current enforcement, and also a good predictor of potential informality. ${ }^{28}$ The other variables play a similar role. We include an additional variable at the subregion level, which measures the number of total labor fines per 1000 firms in the subregion. This is a measure of general enforcement of labor law (as opposed to specific enforcement of worker registration) which is likely to be correlated with the level of general illegal behavior in the subregion and also with its level of development, for reasons already discussed. We assume that, conditional on these characteristics, the variation in enforcement is exogenous to the firm.

We are fairly confident this is a valid assumption and start by presenting the results for this specification. However, in the next section we provide some specification checks as well as several instrumental variable estimates, where our instruments for enforcement are measures of access of inspectors to the cities in their subregion (number of train stations, average area of a city and number of smaller delegations of the Ministry of Labor in the subregion $^{29}$ ) and a measure of general law enforcement in the subregion (homicide rate $^{30}$ ). We will show that our results are robust to the inclusion of different sets of controls, and to accounting for endogeneity using our various instruments.

Table 2 presents the main results of the paper. Each column shows the least square estimate of $\beta$ (from equation (4.1)) for each dependent variable we consider, conditioning on the controls described above. We cluster the standard errors by subregion to account for the fact that enforcement varies at this level while our dependent variables vary at the firm level (some of the remaining controls vary at the level of the firm and others at the level of as dependent variables) because they are all endogeneous variables.

${ }^{28}$ We include them separately because we could not find data on population levels per city in 1985, which would allow us to construct per capita GDP per city in 1985.

${ }^{29}$ The idea is that costly access to cities decreases the amount of inspections and fines faced by firms without being correlated with the error term in the regression. We control for transporation costs to the nearest capital since access to a region and development are likely to be correlated. The inclusion of this variable does not make much different for our estimates.

${ }^{30}$ The idea is that the homicide rate is correlated with the level of general law enforcement in the region and does not directly affect our outcomes of interest. Furthermore, we assume that general law enforcement and enforcement of labor law are positively correlated. 
the subregion).

The first column of the table shows that stricter enforcement of labor regulation strongly affects the demand for informal labor by firms. ${ }^{31}$ Therefore, enforcement is a tool that can potentially be used by governments to effectively fight noncompliance with the law. We estimate that, on average, when the number of fines per 1000 firms in the subregion increases by 1 , the share of informal workers falls by 3.5 percentage points. In our sample, the average number of fines per 1000 firms in the subregion is 0.77 and the average proportion of informal workers in a firm is 0.23 . Based on these numbers we compute that an elasticity of illegal employment with respect to enforcement of -0.12 . This number is comparable to those obtained in the crime deterrence literature using US data: for example, Levitt (1998) finds that the elasticity of crime with respect to the arrest rate is about -0.2 , and Bar-Ilan and Sacerdote (2004) find that the elasticity of driving violations with respect to fines is also about -0.2 . However, average enforcement of labor regulation is low and the average amount of violations is relatively high in our sample, so that an elasticity of -0.12 corresponds to a large absolute effect of fines on illegal behavior.

Given the strength of the effect of enforcement on informality, we are likely to also find effects on productivity as well. Columns (2) to (5) of table 2 show that weaker enforcement of labor regulation is associated with higher firm productivity as measured by value added per worker, average wages, sales per worker and profits per worker. Furthermore, it is interesting that weaker enforcement is also associated with higher investment in capital and technology. This suggests that labor productivity increases because the firm operates more efficiently and the capital stock is higher. We estimate that an increase in 1 in the number of fines per

\footnotetext{
${ }^{31}$ Due to the unusual nature of our dependent variable and to the way the question is asked in the survey we may be concerned with measurement error. Measurement error in the dependent variable is not usually a problem, unless it is correlated with the independent variable of interest. In particular, firms may underreport informal behavior when they are faced with strict enforcement, in which case the coefficient of interest captures the effect of enforcement on both informal behavior and miss reporting and therefore is an overestimate of the true deterrent effect of enforcement. Even though we cannot address this concern in our paper we have replicated our results using a transformation of our dependent variable: a dummy which takes the value 0 if the firm reports no illegal employment and the value 1 if the firm reports any informal employment, although there is no way to say whether this transformation exarcebates or dampens the potential measurement error problem. Our results are essentially the same but some of the standard errors in our instrumental variables specifications in the next section are larger. These results are available on request.
} 
1000 firms in the subregion leads to a reduction of $12.5 \%$ in value added per employee (which means that the elasticity of productivity with respect to enforcement is approximately 0.1 ).

The absence of discernible effects on total employment is rather surprising. When faced with the possibility of hiring informal workers firms decide not to change the size of their labor force, in spite of lower labor costs. Instead, they increase their investment and change their technology (the technological change changes the demand for labor, and in our case it seems to reduce it). They just substitute away from formal workers and towards informal workers. In this instance, increased labor market flexibility does not produce strong effects on employment, but in spite of that (this section shows that) labor market flexibility can have a substantial impact on the economy. In fact, our finding is somewhat consistent with Barros and Corseuil (2001) who find very small effects on employment of tighter labor market regulation due to the 1988 constitutional change (although they do not examine other firm outcomes). ${ }^{32}$ It is quite possible that there are small effects on employment and large effects on other firm outcomes. ${ }^{33}$ Our findings illustrate the importance of looking at multiple outcomes of the firm.

\subsection{Robustness and Endogeneity}

Our estimates are quite robust to several changes in the specification. Table 3 reports the least squares estimates of equation (4.1) using as dependent variable the proportion of informal employment. In column (1) we include only enforcement in the regression. The effect of enforcement on informal employment is strongly negative. ${ }^{34}$ Our estimates of $\beta$ in column (1) will be an underestimate of the true effect if more enforcement is caused by more informality (reverse causality), and it will be an overestimate if strong enforcement and low informality are caused by a third factor, such as strong institutions and strong civic culture

\footnotetext{
${ }^{32}$ Gruber (1997) also finds small effects of social security provisions on employment using data from Chile.

${ }^{33}$ Even though the effect of enforcement on employment is not large, enforcement has an effect on the reported desire of the firm to change its labor force. Firms are asked whether they would change the size of their labor force if they could hire and fire with no restrictions. In results available on request we find that an increase in our measure of enforcement in 1 unit leads to an increase of $4 \%$ in the probability that the firm reports a desire to change the labor force in the absence of hiring or firing constraints.

${ }^{34}$ Using labor inspections as an enforcement measure does not produce such a strong negative correlation as using fines (available on request).
} 
(omitted variables) or if there is sorting. In column (2), we include in the regression controls for differences across subregions in other characteristics that were omitted and that are likely to be relevant for informality and also for enforcement (GDP per capita, population, number of firms, average years of schooling and share of females). In column (3) we control for age of the firm, share of public ownership in the firm and industry dummies. In column (4) we add a control for the total number of labor related fines per 1000 firms in the subregion, which is meant to capture the general severity of labor inspectors in the region. Finally, in columns (5) and (6) we include additional controls at the city and at the firm level. ${ }^{35}$ Across columns the effect of enforcement on employment of informal workers is strong and negative.

We are confident that the variation in enforcement in our preferred specification (column 4) is fairly exogenous. Enforcement is likely not to be uniform across subregions because Brazil covers a very large and diverse geographical area, the number of inspectors involved is also large and most importantly very heterogeneous in their ability and honesty (which is important in the case inspectors are offered bribes). However, there may remain some concerns that $\operatorname{cov}\left(E, \varepsilon_{j} \mid X\right) \neq 0$ so we also present a discussion of possible instruments for the number of informality fines per firm in equation (4.1). We conjecture that some variables that capture the costs of enforcement of regulation are uncorrelated with the firm's decision to hire informal workers except through the extent of enforcement in the subregion. Three of the variables that we propose as instruments measure access of inspectors to different cities within the subregion: the number of train stations in the subregion, average area of a city in the subregion (in thousands of squared kilometers), number of regional offices of the Ministry of Labor in the subregion. The better the access of inspectors to the cities, the lower will be the costs of enforcing the regulation. Still, one may argue that these three variables can be correlated with the performance of the firm because they also measure access to markets, especially the first variable. In order to account for this we include as a control variable an index of the transportation cost to the nearest state capital, which can either be within the

\footnotetext{
${ }^{35}$ If instead of the share of informal workers in the firm we use as dependent variable a dummy variable that equals one if the firm employs any informal workers, we obtain the same patterns (results available on request). The only difference is that the effect corresponding to the one reported on column (2) of table 2 is not significant (but it is still negative). However, all other effects are negative and strongly significant.
} 
state or in a neighboring state. This is a relevant variable for measuring access to markets but not for measuring access from labor inspectors, who operate only within state at the level of the subregion. ${ }^{36}$ Finally, we also propose using as instrument a measure of general enforcement of law in the subregion: average number of homicides per 100000 inhabitants in the cities of the subregion. A priori, there is no reason for the homicide rate to be correlated with informal behavior of the firm except through third factors that are correlated with general enforcement of the law in the subregion and may also affect the enforcement of labor law. ${ }^{37}$

The results of estimating equation (4.1) with instrumental variables are presented in table 4. In each column we instrument registration fines with different combinations of instruments controlling for transportation costs to the nearest capital. Below each instrumental variables specification we present the F-Statistic for a test of whether the instruments are strong in the first stage regression along with the corresponding P-Value, and the P-Value of a Sargan test of overidentification (which we never reject). The results in the table show that the coefficient on enforcement is always strong and negative and, if anything, of larger magnitude than the one in column (1). Because the variable number of train stations is our best measure of access to wider markets, and therefore the most problematic to defend as a valid instrument, we exclude it in columns (4) and (5). ${ }^{38}$ Our results suggest that, if anything, our preferred specification in column (4) of table 3 of the effect of enforcement on informal employment is a conservative estimate.

\footnotetext{
${ }^{36}$ This control variable is more relevant in the case where we examine the effect of fines on the performance of the firm.

${ }^{37}$ Total labor fines can also be seen as a measure of general law enforcement in the subregion. However, we cannot exclude total labor fines from the main regression of interest since total labor fines may also have a direct effect on the demand of informal labor, by potentially affecting the costs of hiring both formal and informal workers. In fact we believe it is better if we use it as a control variable.

${ }^{38} \mathrm{In}$ table A2 in the appendix we study the determinants of fines by regressing registration fines by subregion on subregion controls, including only one observation per subregion (as opposed to weighting by the number of firms in the subregion in the sample). The main determinants of this type of fines are the instrumental variables we use above, log GDP in 1985 (with a negative sign) and total number of labor fines in the subregion (with a positive sign). As shown in column (4) of table 3 (our preferred specification) GDP is also negatively related to firm level informality and total labor fines are positively related to firm level informality, suggesting that reverse causality bias may be more important than third factor bias. Our IV results suggest the same thing since IV coefficients are larger in magnitude than OLS coefficients. If this is the case, if anything our preferred estimate is probably an underestimate of the effect of informality fines on informal employment.
} 
It is also likely that different types of informal behavior are correlated at the firm level. We checked whether enforcement of legal employment was correlated with other types of illegal behavior. In column (1) of table 5 we present the results of a regression of the percentage of sales not reported by the firm to tax authorities on enforcement of formal employment, controlling for the same variables as in column (4) of table 3. We find no evidence of a strong effect of this type of enforcement on tax evasion. ${ }^{39}$ Similarly, if the enforcement of different types of labor regulation are correlated, then both the dependent and independent variables could be capturing other types of informal behavior or other types of fines. We checked whether enforcement of other labor regulations were correlated with the prevalence of informal employment. In columns (2) to (7) of table 5 we report the effect of enforcement of different types of labor regulation on legal employment. We show that the strongest and clearest effect comes through the registration fines, and not through the other fines reported here. These two sets of results suggest that we are doing a good job isolating the relationship between the formal employment enforcement and the prevalence of formal employment. ${ }^{40}$

Table 6 looks at a measure of productivity: log value added per employee. In column (1) we show that labor productivity and enforcement are negatively correlated. When we include subregion and firm controls in columns (2) to (4) the coefficient remains negative. Finally, in column (5) we include city level controls and in column (6) we further add firm level controls that are likely to be endogenous, and which are positively correlated with productivity. The coefficient on registration fines remains large in absolute value and statistically strong. ${ }^{41}$

Instrumental variables estimates are presented in table 7. Except in the case where we include the homicide rate in the set of instruments, our estimates of the effect of fines on firm productivity are negative and statistically strong, and if anything, they are larger

\footnotetext{
${ }^{39}$ Again, the amount of tax evasion is self reported by the firm and therefore is also subject to measurement error. However, in results available on request, we show that firms reporting a smaller fraction of sales for tax purposes also employ more informal workers, are smaller and less produtive than firms who report a large fraction of sales to tax authorities. This indicates that this variables has important informative value.

${ }^{40}$ Table A3 tests the robustness of the effect of enforcement of regulation on the use of informal labor by firms, using alternative measures of enforcement of registration fines. Again, we find negative and significant effects that are robust across the alternative measures.

${ }^{41}$ In Appendix B we show under what conditions we can get upper and lower bounds for the true value of the parameter of interest from the numbers in table 3.
} 
in magnitude than our original estimate. This suggests again that, if anything, ours is a conservative estimate of the effect of enforcement on firm performance.

If enforcement of worker registration through fines is correlated with enforcement of other labor practices then we may be capturing the effect of the latter rather than the effect of the former on informal employment of firms. In appendix table A4 we examine the effect of different types of fines on firm productivity, using our preferred specification of the model where we include firm controls, subregion controls and total labor fines in the subregion. Once again the results suggest that our estimates are not confounding the role of registration fines with the role of other types of fines. ${ }^{42}$ Finally, table A5 tests the robustness of the effect of enforcement of regulation computing alternative measures of enforcement of registration fines. The negative and significant effect is robust across the alternative measures of enforcement. In sum, enforcement of regulation has a strong and robust effect on the firm's value added per worker. ${ }^{43}$

\section{Labor Flexibility and Firm Performance}

In section 4 we showed that stricter enforcement of worker registration leads to lower employment of informal workers. We also showed that stricter enforcement led to worse firm outcomes, and we argued that this was due to a reduction in the firms' access to flexible labor. Drawing on the last two sections, here we present estimates of the effect of labor flexibility on firm performance.

We start by focusing on two measures of firm performance: log value added per employee and log net average wage. A simple way to calculate the effect of labor flexibility on firm performance is to divide the coefficient on informality fines from the performance regressions

\footnotetext{
${ }^{42}$ Apart from registration fines, only transportation subsidy fines (employers in Brazil are obligated to subsidize public transportation of some of their workers) and a residual category of fines are negatively correlated with value added per employee. Notice that the effect of mandatory contribution fines (applied when firms do not pay the required amount to social security) on firm's performance has the "wrong" sign, but that in this regression the measure of total labor fines has a strong negative effect on performance which suggests that the roles of the variables switch. In the last column of the table we include the three variables in the regression simultaneously and we observe that, if anything, the coefficient on informality fines becomes even more negative.

${ }^{43}$ For the sake of brevity, we only present a robustness analysis for this performance variable. Similar analyses for the remaining dependent variables are available on request.
} 
of section 4 by the analogous coefficient from the informality regressions. Taking our preferred specification, the parameters of interest are -3.48 for informal employment, -0.125 for $\log$ value added per employee and -0.045 for log wage (see table 2 ). Therefore, an increase in the proportion of informal employment by 1 percentage point leads to an increase in productivity of $3.59 \%$ (and since the proportion of illegal workers in the average firm in the sample is $23 \%$ this corresponds to an elasticity of productivity with respect to informal employment of 0.83 ) and an increase in wages of $1.29 \%$ (corresponding to an elasticity of 0.3 ). Taking the highest estimate for the effect of registration fines on informal labor from the instrumental variable specifications in table 4 (which is -6.28) and the lowest estimate of the effect of registration fines on value added, from table 6 (which is -0.1), an increase in the proportion of informal employment by 1 percentage point leads to a decrease in productivity of $1.59 \%$ (corresponding to an elasticity of 0.37 ). The corresponding estimate for wages is $-0.045^{44}$, which means that an increase in the proportion of informal employment by 1 percentage points leads to an increase in wages of $0.7 \%$ (an elasticity of 0.16 ). All of these are large in magnitude suggesting that labor flexibility has very strong effects on firm performance.

An alternative way to compute these parameters is to estimate a regression of measures of performance on the firm's informal employment instrumenting informality with enforcement. ${ }^{45}$ In table 8 we present OLS and IV regressions of the effect of the proportion of informal workers hired by the firm on the different measures of firm performance (log value

\footnotetext{
${ }^{44}$ The corresponding table for the IV estimates for the log average wage are not reported but are available on request.

${ }^{45}$ Even if firm level informality is measured with error, we are instrumenting the variable which should be enough to eliminate bias in the coefficient of interest, as long as measurement error is classical. However, measurement error may be not classical in our case. On one end, informal employment is bounded below by zero which may introduce a negative correlation between the true value of the variable and measurement error. On the other end, it is possible to think of several different ways in which respondents decided to answer the informality question and which would lead to non-classical measurement error. For example, in the case where fully legal firms always told the truth and some of the firms employing illegal workers underreported their informal employment there would be a negative correlation between measurement error and the true value of the variable. It may also happen that, since the exact phrasing of the question requires an answer about other firms and not about ones firm, fully legal firms report a positive value for the informality variable because some of its major competitors do employ informal workers, again generating a negative correlation between the report and the true value of the variable. Finally, we have already mentioned that measurement error may be negatively correlated with the instrument if firms underreport more in areas where enforcement is stricter. Unfortunately, it is not possible to predict which of these arguments is more important and what is the resulting sign of the bias.
} 
added per employee, log wage per employee, log sales per employee, log profits per employee, log capital per employee, log total employment and technology dummy). As expected (from our results in table 1) the OLS estimates are both negative, and (as expected from table 2) the IV estimates are positive and large. For example, an increase in the fraction of employed informal workers by 1 percentage point leads to an increase in productivity of $3.5 \%$ (an elasticity of 0.81 ) and an increase in wages of $1.7 \%$ (an elasticity of 0.39 ).

\section{Conclusion}

This paper has two main themes. First, we study the incentives firms face to employ informal workers. In particular, we study the role of enforcement of labor regulation (in the form of labor inspections and labor fines) on the behavior of firms. Second, we analyze how enforcement of formal employment affects firm performance. Stricter enforcement reduces the access of firms to unregulated labor and can damage their productivity by increasing labor costs. Using a combination of firm level data on illegal employment and firm performance, and administrative data on enforcement of regulation, we show that law enforcement reduces informal employment by firms. However, it also reduces the firm's wages, productivity and investment. We argue that this is due to the firm's limited access to flexible labor.

Our paper shows that enforcement of labor regulation in the form of fines can be effectively used as a tool for fighting informality. However, our paper also shows that informal employment is an important source of unregulated labor for Brazilian firms, allowing them to operate more efficiently, and increasing their incentives to invest in new technology. Both of these conclusions have important implications for the design of labor regulation and of its enforcement.

\section{Appendix A - Data}

The data used in the paper comes from a variety of sources and covers thirteen regions

of Brazil: Sao Paulo, Rio de Janeiro, Minas Gerais, Santa Catarina, Rio Grande do Sul, Parana, Goias, Mato Grosso, Ceara, Paraiba, Maranhao, Bahia and Amazonas. 
The firm level data used is the Brazilian investment climate survey collected by the World Bank in 2002. ${ }^{46}$ The criteria used for the sample selection was the representativeness of the population in the specified industrial and regional categories, and diversity in the firm size. To account for these considerations a random sample was stratified using employment has weights. The sample frame covered all the registered firms in the following industrial sectors: food, textile, garments, chemicals, machinery, electronic equipment, auto components and wood products. The selected industries together account for more than $75 \%$ of the manufacturing value added and employment. The first part of the survey, collects information on different topics: general information about the firm and its manager, business environment and business relations, services and government regulations, labor and human resources, production capacity, planning and innovations, supplier and client relations, infrastructure and services inspections, finance. The second part of the survey collects balance sheet information for the 2000-2002 period.

We define next the construction of the main variables in the paper: Employment is the total number of workers in the firm in 2002, Sales per employee is the total sales of the firm in 2002 divided by total number of employees, Value added per employee is the firm's value added divided by the total number of employees, Wages per employee is the total labor cost, excluding mandatory social contributions, Capital per employee is total value of machinery and equipment at the end of 2002, excluding depreciation, divided by total number of employees, Technology developed internally is a dummy variable that assumes the value one when the most important way of acquiring technology is developed within the firm, Share of high educated workers is the share of workers with at least the secondary education, Share of females is the share of females in total workforce, Share workers with training is the share of workers that participated in training offered by the firm in the past year, Share public ownership (foreign) is the share of the firm's capital owned by public (foreign) owners, Tax evasion is the share of the firm's total sales that the manager reports as not being reported for tax purposes, Bribes for government contracts is the share of a total

\footnotetext{
${ }^{46}$ This investment climate survey project has evolved over time within the World Bank. Previous similar projects included the Regional Program on Enterprise Development that has been collecting firm-level data in Sub-Saharan Africa countries for a decade and the World Business Environment Survey.
} 
contract with the government that the manager reports that is expected in bribes to obtain the contract, Individual or family ownership of the firm is a dummy variable that equals one if the largest shareholder of the firm is either an individual or a family, Internal ownership of the firm is a dummy variable that equals one if the largest shareholder of the firm is either the management or the employees, Government ownership is a dummy variable that equals one if the largest shareholder of the firm is the government or a government owned firm, Corporate ownership is a dummy variable that equals one if the largest shareholder of the firm is either a domestic or a foreign firm, Bank ownership is a dummy variable that equals one if the largest shareholder of the firm is a bank or an investment fund, Other ownership includes other types of firm ownership.

Data on the enforcement of labor regulation in 2002 comes from the Ministry of Labor. The federal system of labor inspections, which is part of the Ministry of Labor, has the objective of enforcing all the laws and regulations, including international conventions, related with labor and employment relations and contracts (Law 55.841/65). The inspectors of the federal system of labor inspections verify the enforcement of laws and regulations, including those related with heath and security at work. In particular, they try to avoid labor informality verifying that workers are formally registered with the labor authorities, i.e., that they have a work permit (or carteira de trabalho). The Ministry of Labor is a decentralized structure with a regional branch in each of the 27 Brazilian states ("Delegacia Regional do Trabalho" or DRT). Within each of these branches, there are several administrative units, or subdelegacias. The concept of subdelegacia is administrative and does not correspond to any geographical unit. ${ }^{47}$ In particular, a "subdelegacia" includes more than one city (or municipio). In each subdelegacia there are several regional officies, of which one is the headquarters.

The inspector responsible for each subdelegacia, or the subdelegado, reports to the inspector responsible for the regional branch, the delegado. The labor inspectors (or "Auditores Fiscais do Trabalho") are affiliated only with one subdelegacia. In general, each inspector

\footnotetext{
${ }^{47}$ Brazil is divided into 5 regions (North, Northeast, Center-West, Southeast and South) and 27 "unidades de fomento".
} 
works only for one subdelegacia and reports to the subdelegado. ${ }^{48}$ There is an effort to apply homogeneous criteria in the enforcement of the law throughout the country. This is achieved giving continuous training of the labor inspectors, by having common implementation manual and a similar software. ${ }^{49}$ The inspectors visit the plants with the objective of evaluating the compliance with several dimensions of the labor laws and regulations. For example, they inspect the compliance with regulations related with registration, wages, FGTS, working hours or leave benefits.

We have administrative data collected by the Ministry of Labor in 2002 at the city level for different variables: number of inspected firms in the city, number of fines issued in the city. In particular we have information on the number of fines for different labor violations: informal worker fines, are fines related with the firm not registering the worker for a work permit, work load fines are fines related with the firm not complying with the official work load, wage fines are fines related with the firm not paying the minimum established by the law, hours of work fines are fines related with the firm not complying with the number of hours of work and the mandatory pauses, FGTS fines are fines related with the firm not making the mandatory discounts to the FGTS, transport subsidy fines are fines related with firm not paying the mandatory transport subsidy, and other fines are fines related with other mandatory obligations of the firm to their workers. The total labor fines is simply the sum of all these fines. This information was aggregated from the city level to the subregion level using information provided by the Ministry of Labor on all the cities that belong to each subdelegacia. Finally, we also have information on the number of regional offices in each subregion.

Data for population in 2002 and for the total number of plants in 2002 is collected by the National Statistics Institute (IBGE) at the city level. City level data for GDP (1985), total population (1991) average years of schooling in the population with more than 25

\footnotetext{
${ }^{48}$ This is the case of the inspections related with formal labor contracts. However, for some specific tasks, like anti slavery inspections, inspectors from different subdelegacias can gather to work in a team.

${ }^{49}$ At the end of 2002, there was a total of 2341 labor inspectors in Brazil which were distributed as follows for the federal regions that we cover in the Investment Climate Survey: 35 Amazonas, 103 Bahia, 129 Ceara, 71 Goias, 45 Maranhao, 205 Minas Gerais, 34 Mato Grosso, 99 Parana, 42 Paraiba 294 Rio de Janeiro, 137 Rio Grande do Sul , 73 Santa Catarina and 489 Sao Paulo.
} 
years (2001), share of females (2000), geographical area (2000), transportation costs to the nearest capital city (1995), number of train stations in the city (1995) and homicide rate per 100000 inhabitants (2002) is collected by the Instituto de Pesquisa Economica Aplicada (IPEA). These variables are all observed at the city level. To obtain the corresponding variables at the subregion level, we aggregate the variables from city to the subregion level using information provided by the Ministry of Labor on all the cities that belong to each subdelegacia.

\section{Appendix B - Lower and Upper Bounds for $\beta$}

Consider the following model:

$$
Y=\alpha+\beta E+\gamma X+\varepsilon
$$

where $Y$ is the outcome variable, $E$ is the measure of enforcement and $X$ is a set of endogenous controls, such as employment, capital intensity or human capital of the workers correlated with firms productivity (see the last three columns of the table). Assume that: (1) $\beta<0$ and $\gamma>0 ;(2) C O V(E, \varepsilon)=0$ and $C O V(E, X)<0$, since our results suggest that more productive firms are less targeted by fines; (3) $X$ is endogenous with $\operatorname{COV}(X, \varepsilon)>0$. We have to decide whether to include $X$ or not in the regression.

Excluding $X$ of the regression:

$$
\operatorname{plim} \beta_{O L S}^{1}=\beta+\gamma \frac{C O V(E, X)}{V(E)}<\beta
$$

(where plim indicates probability limit) since (by assumption) $\gamma>0$ and $C O V(E, X)<0$.

Including $X$ in the regression:

$$
\begin{aligned}
\operatorname{plim} \beta_{O L S}^{2} & =\frac{V(X) C O V(E, Y)-C O V(E, X) C O V(X, Y)}{V(E) V(X)-C O V(E, X)^{2}} \\
& =\beta-\frac{C O V(E, X) C O V(X, \varepsilon)}{V(E) V(X)-C O V(E, X)^{2}}>\beta
\end{aligned}
$$

since (by assumption) $C O V(E, X)<0, C O V(X, \varepsilon)>0$ and $V(E) V(X)-C O V(E, X)^{2}>$ 0. Therefore:

$$
\operatorname{plim} \beta_{O L S}^{1}<\beta<\operatorname{plim} \beta_{O L S}^{2}
$$


If our regional controls are not enough to drive $\operatorname{COV}(F, \varepsilon)$ to zero then this formal result breaks down, but the suggestion remains. In particular, suppose $C O V(F, \varepsilon)>0$. Then we would have:

$$
\begin{aligned}
\operatorname{plim} \beta_{O L S}^{1} & =\beta+\gamma \frac{C O V(E, X)}{V(E)}+\frac{C O V(E, \varepsilon)}{V(E)} \\
\operatorname{plim} \beta_{O L S}^{2} & =\beta-\frac{C O V(E, X) C O V(X, \varepsilon)}{V(E) V(X)-C O V(E, X)^{2}}+\frac{C O V(E, \varepsilon)}{V(E)}\left(\frac{1}{1-\rho_{E X}^{2}}\right)
\end{aligned}
$$

where $\rho_{E X}^{2}=\frac{C O V(E, X)^{2}}{V(E) V(X)}$ is between 0 and 1 , so that the effect of $\frac{C O V(E, \varepsilon)}{V(E)}$ is amplified (pushing $\beta_{O L S}$ toward zero). Therefore, provided that in the data $\operatorname{plim} \beta_{O L S}^{1}<\operatorname{plim} \beta_{O L S}^{2}$ (which is probably true from our comparison of columns 4 and 8 in table 5), including this term in our calculations, if anything, strengthens our suggestion that we have upper and lower bounds for $\beta$ and that $\beta$ is indeed strongly negative. 


\section{References}

[1] Bar-Ilan, A. and B. Sacerdote. 2004. "Response to Fines and Probabilities in a Natural Experiment". Journal of Law and Economics, 47(1).

[2] Barros, R. P. and Corseuil, C. 2001. "The impact of regulations on Brazilian Labor Market Performance". Inter-American Development Bank Research Paper \#R-427.

[3] Becker, G. 1962. "Crime and Punishment: An Economic Approach", Journal of Political Economy, 76(9), 169-217.

[4] Besley, T. and Burgess, R. 2004. "Can Labor Regulation Hinder Economic Performance? Evidence from India". Quarterly Journal of Economics, vol. 119(1), pages 91-134.

[5] Blau, F. and L. Kahn. 1996. "International Differences in Male Wage Inequality: Institutions versus Market Forces", Journal of Political Economy, 104(4), 791-837.

[6] Botero, Juan, Simeon Djankov, Rafael La Porta, Florencio Lopez-de-Silanes, and Andrei Shleifer. 2003. "The Regulation of Labor". NBER wp 9756.

[7] Gruber, J. 1997. "The Incidence of Payroll Taxation: Evidence from Chile", Journal of Labor Economics, 15(3), S72-101.

[8] Heckman, James, and Carmen Pages. 2003. Law and Employment: Lessons from Latin American and the Caribbean (Chicago: The University of Chicago Press for the NBER.

[9] Holmes, T. 1998. "The Effect of State Policies on the Location of Manufacturing: Evidence from State Borders", Journal of Political Economy, 106, 667-705.

[10] Johnson, Kaufman, Zoido-Lobaton. 1998 "Regulatory discretion and the unofficial economy", American Economic Review 88, 387-392.

[11] Kugler, Adriana. 2001. "The Incidence of Job Security Regulations on Labor Market Flexibility and Compliance in Colombia: Evidence from the 1990 Reform. in Heckman and Pages, eds., Law and Employment: Lessons from Latin American and the Caribbean (Chicago: The University of Chicago Press for the NBER.

[12] Kugler, Adriana. and Kugler, Maurice. 2003. "The Labor Market Effects of Payroll Taxes in a middle Income country: Evidence from Colombia" . CEPR Discussion Paper No. 4046.

[13] Levitt, S. 1997. "Using Electoral Cicles in Police Hiring to Estimate the Effect of Police on Crime", American Economic Review, 87(3), 270-290.

[14] Levitt, S. 1998. "Juvenile Crime and Punishment", Journal of Political Economy, 106(6), 1156-1185.

[15] Levitt, S. 2004. "Understanding Why Crime Fell in the 1990s: Four Factors that Explain the Decline and Six that Do Not", Journal of Economic Perspectives, 18(1), 163-190. 
[16] Loayza, N..1996. "The Economics of the Informal Sector: A Simple Model and Some Empirical Evidence from Latin America". Carnegie-Rochester Conference Series on Public Policy, 45, 129-62.

[17] Loayza, N., A. Oviedo and L. Serven. 2005. "The Impact of Regulation on Growth and Informality: Cross Country Evidence", World Bank Policy Working Paper 3623.

[18] Maloney, W. 2004. "Informality Revisited". World Development, 32(7), 1159-78.

[19] Nickell, S. and R. Layard. 2000. "Labor Market Institutions and Economic Performance", in O. Ashenfelter and D. Card, eds., "Handbook of Labor Economics", Amsterdam: North Holland.

[20] Nicolleti, G. and Scarpetta, S. 2003. "Regulation, productivity, and growth : OECD evidence". World Bank Discussion Paper.

[21] Oi, W. 1962. "Labor as a Quasi-fixed Factor", Journal of Political Economy, 70(6), 538-555.

[22] Pierre, G. and Scarpetta, S.. 2005. "Employment Regulations through the eyes of employers". mimeo.

[23] Scarpetta, S. and Tressel, Thierry. 2004. "Boosting productivity via innovation and adoption of new technologies: any role for labor market institutions?" World Bank Discussion Paper.

[24] Soares, F. V.. 2004. "Informal Labour Market in Brazil: Job Queue, Trade Liberalization and Minimum Wage". Ph.D. Dissertation University College London.

[25] Svensson, J.. 2003. "Who must pay bribes and how much? Evidence from a cross section of firms". Quarterly Journal of Economics, vol. 118, no. 1, pp. 207-230(24). 
Table 1: Differences between firms with and without informal labor

\begin{tabular}{|c|c|c|}
\hline & $\begin{array}{l}\text { Without Regional and } \\
\text { Sector Controls }\end{array}$ & $\begin{array}{c}\text { With Regional and } \\
\text { Sector Controls }\end{array}$ \\
\hline & (1) & (2) \\
\hline \multirow[t]{2}{*}{ Log employment } & -0.77 & -0.67 \\
\hline & {$[0.059]^{* * *}$} & {$[0.060]^{* * *}$} \\
\hline \multirow[t]{2}{*}{ Log sales per employee } & -0.82 & -0.48 \\
\hline & {$[0.068]^{* * *}$} & {$[0.062]^{* * *}$} \\
\hline \multirow[t]{2}{*}{ Log value added per employee } & -0.76 & -0.46 \\
\hline & {$[0.073]^{* * *}$} & {$[0.069]^{* * *}$} \\
\hline \multirow{2}{*}{ Log wage per employee } & -0.39 & -0.2 \\
\hline & {$[0.052]^{* * *}$} & {$[0.049] * * *$} \\
\hline \multirow[t]{2}{*}{ Log capital per employee } & -0.78 & -0.427 \\
\hline & {$[0.101]^{* * *}$} & {$[0.098]^{* * *}$} \\
\hline \multirow[t]{2}{*}{ Technology developed internaly } & -0.02 & 0.007 \\
\hline & {$[0.023]$} & {$[0.024]$} \\
\hline \multirow[t]{2}{*}{ Share of high educated workers } & -0.06 & -0.031 \\
\hline & {$[0.015]^{* * *}$} & {$[0.015]^{* *}$} \\
\hline \multirow[t]{2}{*}{ Share of females in workforce } & 0.08 & -0.008 \\
\hline & {$[0.017]^{* * *}$} & {$[0.010]$} \\
\hline \multirow[t]{2}{*}{ Share workers with training } & -0.09 & -0.048 \\
\hline & {$[0.019]^{* * *}$} & {$[0.019] * * *$} \\
\hline \multirow[t]{2}{*}{ Age of the firm } & -6.71 & -4.96 \\
\hline & {$[0.913]^{* * *}$} & {$[0.911]^{* * *}$} \\
\hline \multirow{2}{*}{ Share public ownership in the firm } & -0.004 & -0.003 \\
\hline & {$[0.002]^{* *}$} & [0.002] \\
\hline \multirow[t]{2}{*}{ Share foreign ownership in the firm } & -0.066 & -0.044 \\
\hline & {$[0.011]^{* * *}$} & {$[0.011]^{* * *}$} \\
\hline \multirow[t]{2}{*}{ Food Products } & -0.05 & - \\
\hline & {$[0.015]^{* * *}$} & \\
\hline \multirow[t]{2}{*}{ Textile Products } & -0.04 & - \\
\hline & {$[0.013]^{* * *}$} & \\
\hline \multirow{2}{*}{ Clothing } & 0.16 & - \\
\hline & {$[0.024]^{* * *}$} & \\
\hline \multirow[t]{2}{*}{ Shoes and Leather Products } & 0.04 & - \\
\hline & {$[0.017]^{* *}$} & \\
\hline \multirow[t]{2}{*}{ Chemicals } & -0.06 & - \\
\hline & {$[0.012]^{* * *}$} & \\
\hline \multirow[t]{2}{*}{ Machinary } & -0.05 & - \\
\hline & {$[0.017]^{* * *}$} & \\
\hline \multirow[t]{2}{*}{ Electronical Equipment } & -0.03 & - \\
\hline & {$[0.011]^{* *}$} & \\
\hline Auto Components & -0.04 & - \\
\hline & {$[0.015]^{* * *}$} & \\
\hline Wood Products & 0.08 & - \\
\hline & {$[0.022]^{* * *}$} & \\
\hline Tax evasion in the firm & 0.17 & 0.14 \\
\hline & {$[0.013]^{* * *}$} & {$[0.014]^{* * *}$} \\
\hline Bribes for government contracts in the firm & 0.05 & 0.04 \\
\hline & {$[0.009]^{* * *}$} & {$[0.009]^{* * *}$} \\
\hline Individual or family ownership of the firm & 0.13 & 0.08 \\
\hline & {$[0.017]^{* * *}$} & {$[0.017]^{* * *}$} \\
\hline Corporate ownership of the firm & -0.12 & -0.08 \\
\hline & {$[0.015]^{* * *}$} & {$[0.015]^{* * *}$} \\
\hline Bank ownership of the firm & -0.004 & -0.002 \\
\hline & {$[0.003]$} & {$[0.003]$} \\
\hline Internal ownership of the firm & 0.010 & 0.015 \\
\hline & {$[0.008]$} & {$[0.008]^{*}$} \\
\hline Other ownership types in the firm & 0.113 & 0.083 \\
\hline & {$[0.023] * * *$} & {$[0.023]^{* * *} *$} \\
\hline
\end{tabular}

Source: Investment Climate Survey Brazil (2002)

The numbers reported in column (1) are the coefficients of a least square regression of each variable on a dummy variable that assumes the value one if the firm reports a positive share of informal workers. Column (2) adds industry dummies and subregional variables (total number of plants, population in 2002, GDP per capita in 1985 and share of females). Standard errors are clustered at the subregional level. * significant at $10 \%$; ** significant at $5 \%$; *** significant at $1 \%$. See data appendix for the sources and definition of the variables. 
Table 2

Enforcement of Labor Regulation and Manufacturing Performance in Brazil 2002

\begin{tabular}{|c|c|c|c|c|c|c|c|c|}
\hline Dependent variable: & $\begin{array}{c}\text { Share Informal } \\
\text { Workers } \\
(1) \\
\end{array}$ & $\begin{array}{l}\text { Ln Value Added } \\
\text { per Employee } \\
\text { (2) } \\
\end{array}$ & $\begin{array}{c}\text { Ln Wage per } \\
\text { Employee } \\
(3) \\
\end{array}$ & $\begin{array}{c}\text { Ln Sales per } \\
\text { Employee } \\
(4) \\
\end{array}$ & $\begin{array}{c}\text { Ln Profits per } \\
\text { Employee } \\
(5) \\
\end{array}$ & $\begin{array}{c}\text { Ln Capital per } \\
\text { Employee } \\
(6) \\
\end{array}$ & $\begin{array}{c}\text { Ln Total } \\
\text { Employment } \\
(7) \\
\end{array}$ & $\begin{array}{c}\text { Technology } \\
\text { Dummy } \\
(8) \\
\end{array}$ \\
\hline Registration fines per 1000 firms in the subregion & $\begin{array}{c}-3.48 \\
{[1.04]^{* * *}}\end{array}$ & $\begin{array}{c}-0.13 \\
{[0.04]^{* * *}}\end{array}$ & $\begin{array}{c}-0.05 \\
{[0.02]^{* *}}\end{array}$ & $\begin{array}{c}-0.08 \\
{[0.03]^{* *}}\end{array}$ & $\begin{array}{c}-0.20 \\
{[0.05]^{* * *}}\end{array}$ & $\begin{array}{c}-0.09 \\
{[0.04]^{* *}}\end{array}$ & $\begin{array}{c}-0.02 \\
{[0.04]}\end{array}$ & $\begin{array}{c}-0.02 \\
{[0.01]^{*}}\end{array}$ \\
\hline $\begin{array}{l}\text { Industry Dummies Included? } \\
\text { Regional controls Included? }\end{array}$ & $\begin{array}{l}\text { Yes } \\
\text { Yes }\end{array}$ & $\begin{array}{l}\text { Yes } \\
\text { Yes }\end{array}$ & $\begin{array}{l}\text { Yes } \\
\text { Yes }\end{array}$ & $\begin{array}{l}\text { Yes } \\
\text { Yes }\end{array}$ & $\begin{array}{l}\text { Yes } \\
\text { Yes }\end{array}$ & $\begin{array}{l}\text { Yes } \\
\text { Yes }\end{array}$ & $\begin{array}{l}\text { Yes } \\
\text { Yes }\end{array}$ & $\begin{array}{l}\text { Yes } \\
\text { Yes }\end{array}$ \\
\hline $\begin{array}{l}\text { Observations } \\
\text { R squared }\end{array}$ & $\begin{array}{l}1473 \\
0.07\end{array}$ & $\begin{array}{c}1,478 \\
0.27 \\
\end{array}$ & $\begin{array}{c}1,555 \\
0.26 \\
\end{array}$ & $\begin{array}{c}1,574 \\
0.32 \\
\end{array}$ & $\begin{array}{c}1,236 \\
0.18 \\
\end{array}$ & $\begin{array}{c}1,517 \\
0.19 \\
\end{array}$ & $\begin{array}{c}1,638 \\
0.19 \\
\end{array}$ & $\begin{array}{c}0 \\
0.00\end{array}$ \\
\hline
\end{tabular}

The results in the table are the least square estimates of equation (4.1) in the text. Dependent variable varies across columns (1) to (8). Standard errors are clustered at the subregion level. * significant at 10\%; ** significant at

$5 \%$. Total number of plants in the subregion, total population in the subregion, log past GDP in the subregion, log past total population in the subregion, share of Females in the subregion, age of the firm and the share public

ownership of the firm included as regional controls in all the specifications but coefficients not reported. See data appendix for the sources and definition of the variables. 
Table 3

Enforcement of labor regulation and informal workers at the firm level in Brazil

\begin{tabular}{|c|c|c|c|c|c|c|}
\hline & (1) & (2) & (3) & (4) & (5) & (6) \\
\hline Method: & OLS & OLS & OLS & OLS & OLS & OLS \\
\hline \multirow[t]{2}{*}{ Registration fines per 1000 firms in the subregion } & -2.14 & -1.87 & -2.32 & -3.48 & -2.16 & -3.17 \\
\hline & {$[0.58]^{* * *}$} & {$[0.54]^{* * *}$} & {$[0.57]^{* * *}$} & {$[1.04]^{* * *}$} & {$[1.02]^{* *}$} & {$[0.83]^{* * *}$} \\
\hline \multirow[t]{2}{*}{ Total number of plants in the subregion } & - & -10.85 & 1.12 & 6.25 & -115.98 & 22.25 \\
\hline & & [41.33] & [41.43] & [39.55] & [98.09] & {$[38.11]$} \\
\hline \multirow[t]{2}{*}{ Total population in the subregion } & - & 14.87 & 1.64 & -0.55 & 156.94 & -25.05 \\
\hline & & {$[55.90]$} & {$[54.73]$} & [53.08] & [121.31] & [50.19] \\
\hline \multirow[t]{2}{*}{ Log past GDP in the subregion } & - & -6.70 & -3.20 & -4.05 & 2.00 & -3.76 \\
\hline & & {$[2.22]^{* * * *}$} & [2.45] & [2.56] & [2.66] & {$[1.95]^{*}$} \\
\hline \multirow[t]{2}{*}{ Log past total population in the subregion } & - & 9.90 & 6.11 & 6.59 & 0.31 & 6.82 \\
\hline & & {$[2.16]^{* * *}$} & {$[2.41]^{* *}$} & {$[2.41]^{* * *}$} & [2.76] & {$[2.13] * * *$} \\
\hline \multirow[t]{2}{*}{ Share of Females in the subregion } & - & 34.94 & 19.28 & 22.12 & 46.77 & 23.97 \\
\hline & & [36.75] & [37.79] & [38.14] & [40.26] & [28.01] \\
\hline \multirow[t]{2}{*}{ Age of the firm } & - & - & -0.13 & -0.13 & -0.14 & -0.07 \\
\hline & & & {$[0.04]^{* * * *}$} & {$[0.04]^{* * *}$} & {$[0.04]^{* * *}$} & {$[0.03]^{* *}$} \\
\hline \multirow[t]{2}{*}{ Share public ownership of the firm } & - & - & -18.73 & -17.88 & -14.51 & -32.18 \\
\hline & & & {$[8.56]^{* *}$} & {$[8.79]^{* *}$} & [10.33] & {$[11.34]^{* * *}$} \\
\hline \multirow[t]{2}{*}{ Total labor fines per 1000 firms in the subregion } & - & - & - & 0.34 & 0.14 & 0.38 \\
\hline & & & & {$[0.23]$} & {$[0.23]$} & {$[0.21]^{*}$} \\
\hline \multirow[t]{2}{*}{ Total number of plants in the city } & - & - & - & - & 280.22 & - \\
\hline & & & & & {$[136.96]^{* *}$} & \\
\hline \multirow[t]{2}{*}{ Total population in the city } & - & - & - & - & -390.13 & - \\
\hline & & & & & {$[172.35]^{* *}$} & \\
\hline \multirow[t]{2}{*}{ Log past GDP in the city } & - & - & - & - & -4.66 & - \\
\hline & & & & & {$[1.31]^{* * *}$} & \\
\hline \multirow[t]{2}{*}{ Log past total population in the city } & - & - & - & - & 7.15 & - \\
\hline & & & & & {$[1.69]^{* * *}$} & \\
\hline \multirow[t]{2}{*}{ Share of Females in the city } & - & - & - & - & 1.99 & - \\
\hline & & & & & [15.04] & \\
\hline \multirow[t]{2}{*}{ Tax evasion in the firm } & - & - & - & - & - & 29.01 \\
\hline & & & & & & {$[3.22]^{* * *}$} \\
\hline Industry Dummies Included? & No & No & Yes & Yes & Yes & Yes \\
\hline Observations & 1,473 & 1,473 & 1,473 & 1,473 & 1,467 & 1,398 \\
\hline $\mathrm{R}$ squared & 0.01 & 0.02 & 0.07 & 0.07 & 0.09 & 0.15 \\
\hline
\end{tabular}


Table 4

Enforcement of labor regulation and informal workers at the firm level in Brazil

\begin{tabular}{|c|c|c|c|c|c|}
\hline & (1) & (2) & (3) & (4) & $(5)$ \\
\hline Method: & 2 SLS & 2 SLS & 2 SLS & 2 SLS & 2 SLS \\
\hline \multirow[t]{2}{*}{ Registration fines per 1000 firms in the subregion } & -5.40 & -6.13 & -5.75 & -6.28 & -5.05 \\
\hline & $2.619 * *$ & $2.770 * *$ & $2.667 * *$ & $2.373 * * *$ & $2.715^{*}$ \\
\hline \multirow[t]{2}{*}{ Transportation costs to the nearest capital city } & 0.65 & 0.76 & 0.70 & 0.78 & - \\
\hline & 0.40 & $0.409 *$ & $0.406^{*}$ & $0.341 * *$ & \\
\hline
\end{tabular}

Instruments

Number of train Number of train Number of train Number of train Average city area, stations stations, Average

stations, stations, Average Number of

city area Average city city area, regional offices, area, Number Number of Homicide rate of regional regional offices, offices Homicide rate

Regional Controls Included? Industry Dummies Included?

$\begin{array}{ccccc}\text { Yes } & \text { Yes } & \text { Yes } & \text { Yes } & \text { Yes } \\ \text { Yes } & \text { Yes } & \text { Yes } & \text { Yes } & \text { Yes } \\ & & & & \\ 5.01 & 2.97 & 2.23 & 4.48 & 3.48 \\ 0.028 & 0.057 & 0.092 & 0.002 & 0.02 \\ - & 0.47 & 0.45 & 0.64 & 0.45 \\ 1,473 & 1,473 & 1,473 & 1,473 & 1,473\end{array}$

The table reports the instrumental variables estimates of equation (4.1) in the text when the dependent variable is the share of informal workers at the firm level. Standard errors are clustered at the subregion level. * significant at 10\%; ** significant at 5\%. Total number of plants in the subregion, total population in the subregion, log past GDP in the subregion, log past total population in the subregion, share of Females in the subregion, age of the firm and the share public ownership of the firm included as regional controls in all the specifications but coefficients not reported. Number of train stations is the total number of train stations in the subregion, Average city area is the average area of the city in the subregion, number of regional offices is the total number of regional offices in the subregion, Homicide rate is the average number of homicides per 100 thousand inhabitants in the subregion and Transportation costs to the nearest capital city is an index of the transportation cost to the nearest capital city. The overidentification test we employ is due to Sargan (1958). See data appendix for the sources and definition of the variables. 
Table 5

Enforcement of the labor regulation, tax evasion and informality at the firm level in Brazil

\begin{tabular}{|c|c|c|c|c|c|c|c|}
\hline & $(1)$ & $(2)$ & (3) & (4) & $(5)$ & (6) & (7) \\
\hline & $\begin{array}{l}\text { Share sales not } \\
\text { reported for tax } \\
\text { purposes }\end{array}$ & $\begin{array}{c}\text { Share Informal } \\
\text { Employment }\end{array}$ & $\begin{array}{c}\text { Share Informal } \\
\text { Employment }\end{array}$ & $\begin{array}{c}\text { Share Informal } \\
\text { Employment }\end{array}$ & $\begin{array}{c}\text { Share Informal } \\
\text { Employment }\end{array}$ & $\begin{array}{c}\text { Share } \\
\text { Informal } \\
\text { Employment }\end{array}$ & $\begin{array}{c}\text { Share } \\
\text { Informal } \\
\text { Employment }\end{array}$ \\
\hline Method & OLS & OLS & OLS & OLS & OLS & OLS & OLS \\
\hline Registration fines per 1000 firms in the subregion & $\begin{array}{l}-0.005 \\
{[0.010]}\end{array}$ & - & - & - & - & - & - \\
\hline Work load fines per 1000 firms in the subregion & & $\begin{array}{c}1.26 \\
{[3.18]}\end{array}$ & - & - & - & - & - \\
\hline Wage fines per 1000 firms in the subregion & - & - & $\begin{array}{l}-1.03 \\
{[2.60]}\end{array}$ & - & - & - & - \\
\hline Hours fines per 1000 firms in the subregion & - & - & - & $\begin{array}{c}2.8 \\
{[1.55]^{*}}\end{array}$ & - & - & - \\
\hline FGTS fines per 1000 firms in the subregion & - & - & - & - & $\begin{array}{l}1.42 \\
{[1.48]}\end{array}$ & - & - \\
\hline Transport subsidy fines per 1000 firms in the subregion & - & - & - & - & - & $\begin{array}{c}47.5 \\
{[34.24]}\end{array}$ & - \\
\hline Other fines per 1000 firms in the subregion & - & - & - & - & - & - & $\begin{array}{l}0.13 \\
{[1.34]}\end{array}$ \\
\hline Total labor fines per 1000 firms in the subregion & $\begin{array}{c}-0.001 \\
{[0.003]}\end{array}$ & $\begin{array}{c}-0.27 \\
{[0.34]}\end{array}$ & $\begin{array}{c}-0.02 \\
{[0.42]}\end{array}$ & $\begin{array}{c}-0.47 \\
{[0.25]^{*}}\end{array}$ & $\begin{array}{l}-0.57 \\
{[0.41]}\end{array}$ & $\begin{array}{l}-0.31 \\
{[0.20]}\end{array}$ & $\begin{array}{c}-0.19 \\
{[0.37]}\end{array}$ \\
\hline Regional Controls included? & Yes & Yes & Yes & Yes & Yes & Yes & Yes \\
\hline Industry Dummies Included? & Yes & Yes & Yes & Yes & Yes & Yes & Yes \\
\hline $\begin{array}{l}\text { Observations } \\
\text { R squared }\end{array}$ & $\begin{array}{c}1,511 \\
0.10\end{array}$ & $\begin{array}{c}1,473 \\
0.07\end{array}$ & $\begin{array}{c}1,473 \\
0.07\end{array}$ & $\begin{array}{c}1,473 \\
0.07\end{array}$ & $\begin{array}{c}1,473 \\
0.07\end{array}$ & $\begin{array}{c}1,473 \\
0.07\end{array}$ & $\begin{array}{c}1,473 \\
0.07\end{array}$ \\
\hline
\end{tabular}


Table 6

Enforcement of Labor Regulation and Firm's Value Added per Employee in Brazil

\begin{tabular}{|c|c|c|c|c|c|c|}
\hline & (1) & (2) & (3) & (4) & $(5)$ & (6) \\
\hline Method: & OLS & OLS & OLS & OLS & OLS & OLS \\
\hline Registration fines per 1000 firms in the subregion & $\begin{array}{c}-0.10 \\
{[0.04]^{* *}}\end{array}$ & $\begin{array}{c}-0.06 \\
{[0.03]^{*}}\end{array}$ & $\begin{array}{c}-0.04 \\
{[0.03]}\end{array}$ & $\begin{array}{c}-0.13 \\
{[0.04]^{* * *}}\end{array}$ & $\begin{array}{c}-0.12 \\
{[0.04]^{* * * *}}\end{array}$ & $\begin{array}{c}-0.10 \\
{[0.04]^{* * *}}\end{array}$ \\
\hline Total number of plants in the subregion & - & $\begin{array}{c}3.99 \\
{[1.88]^{* *}}\end{array}$ & $\begin{array}{c}2.58 \\
{[1.71]}\end{array}$ & $\begin{array}{c}2.9 \\
{[1.41]^{* *}}\end{array}$ & $\begin{array}{l}-0.31 \\
{[2.73]}\end{array}$ & $\begin{array}{c}1.97 \\
{[1.25]}\end{array}$ \\
\hline Total population in the subregion & - & $\begin{array}{c}-4.74 \\
{[2.52]^{*}}\end{array}$ & $\begin{array}{l}-2.92 \\
{[2.34]}\end{array}$ & $\begin{array}{l}-3.01 \\
{[1.95]}\end{array}$ & $\begin{array}{c}1.6 \\
{[3.33]}\end{array}$ & $\begin{array}{l}-1.78 \\
{[1.69]}\end{array}$ \\
\hline Log past GDP in the subregion & - & $\begin{array}{c}0.77 \\
{[0.14]^{* * *}}\end{array}$ & $\begin{array}{c}0.4 \\
{[0.09]^{* * *}}\end{array}$ & $\begin{array}{c}0.34 \\
{[0.10]^{* * *}}\end{array}$ & $\begin{array}{c}0.09 \\
{[0.10]}\end{array}$ & $\begin{array}{c}0.28 \\
{[0.08]^{* * *}}\end{array}$ \\
\hline Log past total population in the subregion & - & $\begin{array}{c}-0.9 \\
{[0.16]^{* * *}}\end{array}$ & $\begin{array}{c}-0.49 \\
{[0.11]^{* * *}}\end{array}$ & $\begin{array}{c}-0.46 \\
{[0.12]^{* * *}}\end{array}$ & $\begin{array}{l}-0.09 \\
{[0.12]}\end{array}$ & $\begin{array}{c}-0.37 \\
{[0.10]^{* * *}}\end{array}$ \\
\hline Share of Females in the subregion & - & $\begin{array}{l}-1.64 \\
{[1.73]}\end{array}$ & $\begin{array}{c}-0.01 \\
{[1.46]}\end{array}$ & $\begin{array}{c}0.13 \\
{[1.47]}\end{array}$ & $\begin{array}{c}0.05 \\
{[1.50]}\end{array}$ & $\begin{array}{c}0.58 \\
{[1.16]}\end{array}$ \\
\hline Age of the firm & - & - & $\begin{array}{c}0.01 \\
{[0.00]^{* * * *}}\end{array}$ & $\begin{array}{c}0.01 \\
{[0.00]^{* * *}}\end{array}$ & $\begin{array}{c}0.01 \\
{[0.00]^{* * * *}}\end{array}$ & $\begin{array}{c}0.01 \\
{[0.00]^{* * * *}}\end{array}$ \\
\hline Share public ownership of the firm & - & - & $\begin{array}{c}2.12 \\
{[0.68]^{* * * *}}\end{array}$ & $\begin{array}{c}2.20 \\
{[0.68]^{* * *}}\end{array}$ & $\begin{array}{c}1.91 \\
{[0.74]^{* *}}\end{array}$ & $\begin{array}{c}0.63 \\
{[1.10]}\end{array}$ \\
\hline Total labor fines per 1000 firms in the subregion & - & - & - & $\begin{array}{c}0.03 \\
{[0.01]^{* *}}\end{array}$ & $\begin{array}{c}0.02 \\
{[0.01]^{*}}\end{array}$ & $\begin{array}{c}0.02 \\
{[0.01]^{*}}\end{array}$ \\
\hline Total number of plants in the city & - & - & - & - & $\begin{array}{c}3.58 \\
{[3.90]}\end{array}$ & - \\
\hline Total population in the city & - & - & - & - & $\begin{array}{l}-5.27 \\
{[4.91]}\end{array}$ & - \\
\hline Log past GDP in the city & - & - & - & - & $\begin{array}{c}0.27 \\
{[0.08]^{* * * *}}\end{array}$ & - \\
\hline Log past total population in the city & - & - & - & - & $\begin{array}{c}-0.34 \\
{[0.09]^{* * * *}}\end{array}$ & - \\
\hline Share of Females in the city & - & - & - & - & $\begin{array}{c}0.34 \\
{[0.62]}\end{array}$ & - \\
\hline Ln employment in the firm & - & - & - & - & - & $\begin{array}{c}0.19 \\
{[0.03]^{* * *}}\end{array}$ \\
\hline Share of high educated workers in the firm & - & - & - & - & - & $\begin{array}{c}0.29 \\
{[0.08]^{* * *}}\end{array}$ \\
\hline Ln capital per employee in the firm & - & - & - & - & - & $\begin{array}{c}0.23 \\
{[0.03]^{* * *}}\end{array}$ \\
\hline Industry Dummies Included? & No & No & Yes & Yes & Yes & Yes \\
\hline $\begin{array}{l}\text { Observations } \\
\text { R squared }\end{array}$ & $\begin{array}{l}1,478 \\
0.005\end{array}$ & $\begin{array}{c}1,478 \\
0.09\end{array}$ & $\begin{array}{c}1,478 \\
0.27\end{array}$ & $\begin{array}{c}1,478 \\
0.27\end{array}$ & $\begin{array}{c}1,473 \\
0.28\end{array}$ & $\begin{array}{c}1,432 \\
0.38 \\
\end{array}$ \\
\hline
\end{tabular}

The results in the table are the least squares estimates of equation (4.1) in the text when the dependent variable is the logarithm of the value added per employee at the firm level.

Standard errors are clustered at the subregion level. * significant at $10 \%$;* significant at $5 \%$; *** significant at $1 \%$. See data appendix for the sources and definition of the

variables. 
Table 7

Enforcement of Labor Regulation and Firm's Value Added per Employee in Brazil

\begin{tabular}{|c|c|c|c|c|c|}
\hline & $(1)$ & (2) & (3) & (4) & $(5)$ \\
\hline Method: & 2 SLS & 2SLS & 2SLS & 2 SLS & 2SLS \\
\hline \multirow[t]{2}{*}{ Registration fines per 1000 firms in the subregion } & -0.15 & -0.15 & -0.15 & -0.10 & -0.10 \\
\hline & {$[0.090]^{*}$} & {$[0.087]^{*}$} & {$[0.086]^{*}$} & {$[0.078]$} & [0.099] \\
\hline \multirow[t]{2}{*}{ Transportation costs to the nearest capital city } & 0.14 & 0.14 & 0.14 & 0.16 & - \\
\hline & {$[0.143]$} & {$[0.147]$} & {$[0.148]$} & {$[0.140]$} & \\
\hline
\end{tabular}

Instrument

Number of train Number of train Number of train Number of train Average city stations stations,

Average city

area

stations,

stations,

area, Number of

Average city Average city regional offices, area, Number of area, Number of Homicide rate regional offices regional offices,

Homicide rate

Regional Controls Included?

Industry Dummies Included?

$F$-test instruments

$p$ value

Yes

Yes

Yes

Yes

5.01

0.028

2.97

0.057

0.92

1,478

1,478

478

\begin{abstract}
Yes
\end{abstract}
Yes

2.23

0.092

0.99

1,478

1,478

\section{Yes}

Yes

Yes

Yes

3.48

4.48

0.002

0.02

Observations

level. Standard errors are clustered at the subregion level. * significant at 10\%; ** significant at 5\%. Total number of plants in the subregion, total population in the subregion, $\log$ past GDP in the subregion, log past total population in the subregion, share of Females in the subregion, age of the firm and the share public ownership of the firm included as regional controls in all the specifications but coefficients not reported. Number of train stations is the total number of train stations in the subregion, Average city area is the average area of the city in the subregion, number of regional offices is the total number of regional offices in the subregion, Homicide rate is the average number of homicides per 100 thousand inhabitants in the subregion and Transportation costs to the nearest capital city is an index of the transportation cost to the nearest capital city. The overidentification test we employ is due to Sargan (1958). See data appendix for the sources and definition of the variables. 
Table 8

Manufacturing performance and the share of informal workers in Brazil

\begin{tabular}{|c|c|c|c|c|c|c|c|}
\hline Dependent variable: & $\begin{array}{c}\text { Ln Value Added } \\
\text { per Employee } \\
(1) \\
\end{array}$ & $\begin{array}{c}\text { Ln Wage per } \\
\text { Employee } \\
(2)\end{array}$ & $\begin{array}{c}\text { Ln Sales per } \\
\text { Employee } \\
(3) \\
\end{array}$ & $\begin{array}{l}\text { Ln Profits per } \\
\text { Employee } \\
(4) \\
\end{array}$ & $\begin{array}{c}\text { Ln Capital per } \\
\text { Employee } \\
(5) \\
\end{array}$ & $\begin{array}{c}\text { Ln Total } \\
\text { Employment } \\
(6) \\
\end{array}$ & $\begin{array}{l}\text { Technology } \\
\text { Dummy } \\
(7) \\
\end{array}$ \\
\hline \multicolumn{8}{|c|}{ Panel A. OLS Estimate } \\
\hline \multirow[t]{2}{*}{ Share of informal workers in firm } & -0.01 & -0.002 & -0.007 & -0.007 & -0.004 & -0.008 & -0.0002 \\
\hline & {$[0.001]^{* * *}$} & {$[0.001]^{* *}$} & {$[0.001]^{* * *}$} & {$[0.002]^{* * *}$} & {$[0.002] * *$} & {$[0.001]^{* * *}$} & [0.00039] \\
\hline Industry dummies included? & Yes & Yes & Yes & Yes & Yes & Yes & Yes \\
\hline Regional controls included? & Yes & Yes & Yes & Yes & Yes & Yes & Yes \\
\hline Observations & 1,401 & 1,331 & 1,401 & 1,416 & 1,110 & 1,366 & 1,473 \\
\hline R squared & 0.33 & 0.28 & 0.25 & 0.34 & 0.17 & 0.18 & 0.23 \\
\hline \multicolumn{8}{|c|}{ Panel B. 2SLS Estimates } \\
\hline Share of informal workers in the firm & $\begin{array}{c}0.035 \\
{[0.017]^{* *}}\end{array}$ & $\begin{array}{c}0.017 \\
{[0.009]^{*}}\end{array}$ & $\begin{array}{c}0.020 \\
{[0.013]}\end{array}$ & $\begin{array}{c}0.051 \\
{[0.029]^{*}}\end{array}$ & $\begin{array}{c}0.020 \\
{[0.014]}\end{array}$ & $\begin{array}{c}0.011 \\
{[0.014]}\end{array}$ & $\begin{array}{c}0.007 \\
{[0.003]^{*}}\end{array}$ \\
\hline Instrument: & $\begin{array}{l}\text { Registration fines } \\
\text { per } 1000 \text { firms in } \\
\text { the subregion }\end{array}$ & $\begin{array}{l}\text { Registration fines } \\
\text { per } 1000 \text { firms in } \\
\text { the subregion }\end{array}$ & $\begin{array}{l}\text { Registration fines } \\
\text { per } 1000 \text { firms in } \\
\text { the subregion }\end{array}$ & $\begin{array}{l}\text { Registration fines } \\
\text { per } 1000 \text { firms in } \\
\text { the subregion }\end{array}$ & $\begin{array}{l}\text { Registration fines } \\
\text { per } 1000 \text { firms in } \\
\text { the subregion }\end{array}$ & $\begin{array}{l}\text { Registration fines } \\
\text { per } 1000 \text { firms in } \\
\text { the subregion }\end{array}$ & $\begin{array}{l}\text { Registration fines } \\
\text { per } 1000 \text { firms in } \\
\text { the subregion }\end{array}$ \\
\hline Industry dummies included? & Yes & Yes & Yes & Yes & Yes & Yes & Yes \\
\hline Regional controls included? & Yes & Yes & Yes & Yes & Yes & Yes & Yes \\
\hline Observations & 1,401 & 1,331 & 1,401 & 1,416 & 1,110 & 1,366 & 1,473 \\
\hline
\end{tabular}

Panel A reports the least square estimates of different dependent variables on the share of informal workers in the firm, controling for other firm and regional characteristics. Panel B instruments the share of informal workers with registration fines per 1000 firms in the subregion. Total number of plants in the subregion, total population in the subregion, log past GDP in the subregion, log past total population in the subregion, share of Females in the subregion, age of the firm and the share public ownership of the firm, the total labor fines per 1000 firms in the subregion and industry dummies included as controls in all the specifications but coefficients not reported. Standard errors are clustered at the subregion. * significant at $10 \% ; * *$ significant at $5 \% ; * * *$ significant at $1 \%$. See data appendix for the sources and definition of the variables. 
Table A1: Summary Statistics

\begin{tabular}{|c|c|c|c|c|c|}
\hline & Obs & Mean & Std. Dev. & Min & Max \\
\hline Ln Employment & 1,641 & 4.0 & 1.14 & 1.8 & 8.9 \\
\hline Ln Sales per Employee & 1,577 & 10.7 & 1.26 & 7.1 & 17.5 \\
\hline Ln Value Added per Employee & 1,480 & 8.9 & 1.33 & 4.1 & 16.7 \\
\hline Ln Wage per Employee & 1,558 & 8.7 & 0.94 & 4.0 & 14.7 \\
\hline Ln Capital per Employee & 1,520 & 7.0 & 1.80 & -2.0 & 14.0 \\
\hline Technology & 1,641 & 0.77 & 0.42 & 0 & 1 \\
\hline Share of High Educated Workers & 1,635 & 0.46 & 0.28 & 0 & 1 \\
\hline Share Females & 1,631 & 0.38 & 0.31 & 0 & 1.0 \\
\hline Share of Workers with Training & 1,520 & 0.29 & 0.33 & 0 & 1 \\
\hline Age of the firm & 1,641 & 18.2 & 17.08 & 0 & 122 \\
\hline Share Public Ownership & 1,641 & 0.002 & 0.03 & 0 & 1 \\
\hline Share Foreign Ownership & 1,641 & 0.05 & 0.20 & 0 & 1 \\
\hline Manuf. Food Products & 1,641 & 0.08 & 0.27 & 0 & 1 \\
\hline Manuf. Textile Products & 1,641 & 0.06 & 0.24 & 0 & 1 \\
\hline Manuf. Clothing & 1,641 & 0.27 & 0.44 & 0 & 1 \\
\hline Manuf. Shoes and Leather Products & 1,641 & 0.11 & 0.31 & 0 & 1 \\
\hline Manuf. Chemicals & 1,641 & 0.05 & 0.22 & 0 & 1 \\
\hline Manuf. Machinary & 1,641 & 0.11 & 0.32 & 0 & 1 \\
\hline Manuf. Electronical Equipment & 1,641 & 0.05 & 0.21 & 0 & 1 \\
\hline Manuf. Auto Components & 1,641 & 0.08 & 0.27 & 0 & 1 \\
\hline Manuf. Wood Products & 1,641 & 0.19 & 0.39 & 0 & 1 \\
\hline Number of Plants in the subregion / 1000000000 & 1,640 & 0.11 & 0.15 & 0.01 & 0.6 \\
\hline Total Population in the subregion / 1000000000 & 1,640 & 0.08 & 0.12 & 0.002 & 0.5 \\
\hline GDP per capita in the subregion / 1000000000 & 1,640 & 0.03 & 0.03 & 0.002 & 0.4 \\
\hline Av. years of schooling in the subregion & 1,640 & 5.25 & 1.21 & 2.64 & 8.42 \\
\hline Share of Females in the subregion & 1,640 & 0.38 & 0.04 & 0.29 & 0.45 \\
\hline Registration fines per 1000 firms in the subregion & 1,638 & 0.77 & 0.90 & 0 & 5.85 \\
\hline Work Load Fines per 1000 firms in the subregion & 1,638 & 0.44 & 0.49 & 0 & 2.48 \\
\hline Hours Fines per 1000 firms in the subregion & 1,638 & 0.53 & 0.71 & 0 & 3.80 \\
\hline Wage Fines per 1000 firms in the subregion & 1,638 & 0.70 & 0.74 & 0 & 4.10 \\
\hline FGTS Fines per 1000 firms in the subregion & 1,638 & 1.57 & 1.52 & 0.02 & 11.0 \\
\hline Transport Subsidy Fines per 1000 firms in the subregion & 1,638 & 0.01 & 0.02 & 0 & 0.2 \\
\hline Other Fines per 1000 firms in the subregion & 1,638 & 1.09 & 1.14 & 0.04 & 7.6 \\
\hline Total Labor Fines per 1000 firms in the subregion & 1,638 & 5.12 & 4.53 & 0.17 & 25.9 \\
\hline
\end{tabular}


Table A2

Determinants of Registration Fines in the subregion in Brazil

\begin{tabular}{|c|c|c|c|c|c|c|c|}
\hline & $(1)$ & $(2)$ & $(3)$ & $(4)$ & $(5)$ & $(6)$ & $(7)$ \\
\hline Total labor fines per 1000 firms in the subregion & $\begin{array}{c}0.13 \\
{[0.02]^{* * *}}\end{array}$ & $\begin{array}{c}0.13 \\
{[0.02]^{* * *}}\end{array}$ & $\begin{array}{c}0.14 \\
{[0.02]^{* * *}}\end{array}$ & $\begin{array}{c}0.14 \\
{[0.02]^{* * *}}\end{array}$ & $\begin{array}{c}0.13 \\
{[0.02]^{* * *}}\end{array}$ & $\begin{array}{c}0.13 \\
{[0.02]^{* * *}}\end{array}$ & $\begin{array}{c}0.13 \\
{[0.02]^{* * *}}\end{array}$ \\
\hline Total number of plants in the subregion & $\begin{array}{c}0.49 \\
{[3.90]}\end{array}$ & $\begin{array}{c}0.49 \\
{[3.93]}\end{array}$ & $\begin{array}{c}0.81 \\
{[4.37]}\end{array}$ & $\begin{array}{c}4.91 \\
{[4.50]}\end{array}$ & $\begin{array}{c}0.05 \\
{[4.43]}\end{array}$ & $\begin{array}{c}-0.92 \\
{[4.43]}\end{array}$ & $\begin{array}{c}-1.25 \\
{[4.55]}\end{array}$ \\
\hline Total population in the subregion & $\begin{array}{c}-0.49 \\
{[4.99]}\end{array}$ & $\begin{array}{c}-0.48 \\
{[5.03]}\end{array}$ & $\begin{array}{c}-0.59 \\
{[5.60]}\end{array}$ & $\begin{array}{l}-5.91 \\
{[5.75]}\end{array}$ & $\begin{array}{c}0.39 \\
{[5.70]}\end{array}$ & $\begin{array}{c}1.45 \\
{[5.68]}\end{array}$ & $\begin{array}{c}1.91 \\
{[5.86]}\end{array}$ \\
\hline Log past GDP in the subregion & $\begin{array}{c}-0.41 \\
{[0.15]^{* * *}}\end{array}$ & $\begin{array}{c}-0.41 \\
{[0.15]^{* * *}}\end{array}$ & $\begin{array}{c}-0.22 \\
{[0.15]}\end{array}$ & $\begin{array}{c}-0.26 \\
{[0.15]^{*}}\end{array}$ & $\begin{array}{c}-0.2 \\
{[0.16]}\end{array}$ & $\begin{array}{c}-0.37 \\
{[0.15]^{* *}}\end{array}$ & $\begin{array}{c}-0.36 \\
{[0.15]^{* *}}\end{array}$ \\
\hline Log past total population in the subregion & $\begin{array}{c}0.07 \\
{[0.16]}\end{array}$ & $\begin{array}{c}0.07 \\
{[0.17]}\end{array}$ & $\begin{array}{c}0.16 \\
{[0.18]}\end{array}$ & $\begin{array}{c}0.14 \\
{[0.18]}\end{array}$ & $\begin{array}{c}0.18 \\
{[0.18]}\end{array}$ & $\begin{array}{c}0.09 \\
{[0.16]}\end{array}$ & $\begin{array}{c}0.09 \\
{[0.17]}\end{array}$ \\
\hline Share of Females in the subregion & $\begin{array}{c}-1.43 \\
{[2.44]}\end{array}$ & $\begin{array}{c}-1.13 \\
{[2.79]}\end{array}$ & $\begin{array}{c}-5.41 \\
{[2.85]^{*}}\end{array}$ & $\begin{array}{c}-4.34 \\
{[2.64]}\end{array}$ & $\begin{array}{c}-2.28 \\
{[2.72]}\end{array}$ & $\begin{array}{c}-0.79 \\
{[2.94]}\end{array}$ & $\begin{array}{c}-0.64 \\
{[2.99]}\end{array}$ \\
\hline Number of train stations in the subregion & $\begin{array}{c}0.03 \\
{[0.01]^{* * *}}\end{array}$ & $\begin{array}{c}0.03 \\
{[0.01]^{* * *}}\end{array}$ & - & - & - & $\begin{array}{c}0.02 \\
{[0.01]^{* * *}}\end{array}$ & $\begin{array}{c}0.02 \\
{[0.01]^{* * *} *}\end{array}$ \\
\hline Transportation Costs to the nearest capital city & - & $\begin{array}{c}0.08 \\
{[0.35]}\end{array}$ & - & - & - & - & $\begin{array}{c}0.22 \\
{[0.61]}\end{array}$ \\
\hline Average city area in the subregion & - & - & $\begin{array}{c}-0.05 \\
{[0.03]}\end{array}$ & - & - & $\begin{array}{c}-0.01 \\
{[0.03]}\end{array}$ & $\begin{array}{c}-0.02 \\
{[0.05]}\end{array}$ \\
\hline Number of regional offices in the subregion & - & - & - & $\begin{array}{c}0.03 \\
{[0.01]^{*}}\end{array}$ & - & $\begin{array}{l}0.000 \\
{[0.01]}\end{array}$ & $\begin{array}{c}0.000 \\
{[0.01]}\end{array}$ \\
\hline Homicide rate in the subregion & - & - & - & - & $\begin{array}{c}-0.01 \\
{[0.00]^{*}}\end{array}$ & $\begin{array}{c}-0.01 \\
{[0.00]}\end{array}$ & $\begin{array}{c}-0.01 \\
{[0.00]}\end{array}$ \\
\hline $\begin{array}{l}\text { Observations } \\
\text { R squared }\end{array}$ & $\begin{array}{c}77 \\
0.54\end{array}$ & $\begin{array}{c}77 \\
0.54\end{array}$ & $\begin{array}{c}77 \\
0.44\end{array}$ & $\begin{array}{c}77 \\
0.45\end{array}$ & $\begin{array}{c}77 \\
0.45\end{array}$ & $\begin{array}{c}77 \\
0.56\end{array}$ & $\begin{array}{c}77 \\
0.56\end{array}$ \\
\hline
\end{tabular}

The coefficients reported are the least square regression of registration fines per 1000 firms in the subregion on different explanatory variables at the subregional level. Standard errors are clustered at the subregion level. * significant at 10\%; ** significant at 5\%; *** significant at $1 \%$. The regressions includes one observation per subregion in our sample. Number of train stations is the total number of train stations in the subregion, Average city area is the average area of the city in the subregion, number of regional offices is the total number of regional offices in the subregion, Homicide rate is the average number of homicides per 100 thousand inhabitants in the subregion and Transportation costs to the nearest capital city is an index of the transportation cost to the nearest capital city. 
Table A3

Enforcement of labor regulation and informal workers at the firm level: Robustness to Different Enforcement Measures

Registration fines per 1000 inspected firms in manufacturing in subregion

$-91.2$

$[27.14]^{* * * *}$

12.82

Total labor fines per 1000 inspected firm in manufacturing in subregion

Registration fines per 1000 inspected firm in subregion

Total labor fines per 1000 inspected firms in subregion

Registration fines per person in subregion

Total labor fines per person in subregion

Industry Dummies Included?

Regional controls Included?

Observations

$\mathrm{R}$ squared

The results in the table are the least squares estimates of equation (4.1) in the text with different control variables when the dependent variable is the share of

number of plants in the subregion, total population in the subregion, log past GDP in the subregion, log past total population in the subregion, share of Females in

the subregion, age of the firm and the share public ownership of the firm included as regional controls in all the specifications but coefficients not reported. See data appendix for the sources and definition of the variables. 
Table A4

Enforcement of Different Labor Regulations and Firm's Value Added per Employee in Brazil

(2) (3)

(4)

$(5)$

Registration fines per 1000 firms in the subregion

$-0.13$

Work load fines per 1000 firms in the subregion $[0.04]^{* * *}$

Wage fines per 1000 firms in the subregion

Hours fines per 1000 firms in the subregion

FGTS fines per 1000 firms in the subregion

Transport subsidy fines per 1000 firms in the subregion

Other fines per 1000 firms in the subregion

\begin{tabular}{|c|c|c|c|c|c|c|}
\hline- & $\begin{array}{l}-0.15 \\
{[0.15]}\end{array}$ & - & - & - & - & - \\
\hline- & - & $\begin{array}{c}0.12 \\
{[0.10]}\end{array}$ & - & - & - & - \\
\hline- & - & - & $\begin{array}{l}-0.10 \\
{[0.08]}\end{array}$ & - & - & - \\
\hline- & - & - & - & $\begin{array}{c}0.18 \\
{[0.04]^{* * *}}\end{array}$ & - & - \\
\hline - & - & - & - & - & $\begin{array}{c}-2.16 \\
{[1.14]^{*}}\end{array}$ & - \\
\hline- & - & - & - & - & - & $\begin{array}{c}-0.12 \\
{[0.06]^{* *}}\end{array}$ \\
\hline Yes & Yes & Yes & Yes & Yes & Yes & Yes \\
\hline Yes & Yes & Yes & Yes & Yes & Yes & Yes \\
\hline 1,478 & 1,478 & 1,478 & 1,478 & 1,478 & 1,478 & 1,478 \\
\hline 0.27 & 0.27 & 0.27 & 0.27 & 0.27 & 0.27 & 0.27 \\
\hline
\end{tabular}

\begin{tabular}{lcccccc} 
Industry Dummies Included? & Yes & Yes & Yes & Yes & Yes & $\begin{array}{c}\text { Yes } \\
\text { Yes }\end{array}$ \\
Regional controls Included? & Yes & Yes & Yes & Yes & & \\
& & & & & \\
Observations & 1,478 & 1,478 & 1,478 & 1,478 & 1,478 \\
R squared & 0.27 & 0.27 & 0.27 & 0.27 & 0.27 & 0.27 \\
\hline \hline
\end{tabular}

The results in the table are the least squares estimates of equation (4.1) in the text with different control variables when the dependent variable is the logarithm of the value added per employee at the firm level. Standard errors are clustered at the subregion level. * significant at 10\%; ** significant at 5\%; *** significant at $1 \%$. See data appendix for the sources and definition of the variables. Total number of plants in the subregion, total population in the subregion, log past GDP in the subregion, log past total population in the subregion, share of Females in the subregion, age of the firm and the share public ownership of the firm included as regional controls in all the specifications but coefficients not reported. 
Table A5

Enforcement of Labor Regulation and Firm's Value Added per Employee: Robustness to Different Enforcement Measures

Registration fines per 1000 inspected firms in manufacturing in the subregion

Total labor fines per inspected 1000 firms in manufacturing in the subregion

Registration fines per inspected firm in the subregion

Total Labor Fines per inspected firm in the subregion

Registration fines per person in the subregion

Total labor fines per person in the subregion

Industry Dummies Included?

Regional controls Included?

Observations

R squared

The results in the table are the least squares estimates of equation (4.1) in the text with different control variables when the dependent variable is the share

of informal workers at the firm level. Standard errors are clustered at the subregion level. * significant at 10\%; ** significant at 5\%; *** significant at $1 \%$.

Total number of plants in the subregion, total population in the subregion, log past GDP in the subregion, log past total population in the subregion, share

of Females in the subregion, age of the firm and the share public ownership of the firm included as regional controls in all the specifications but coefficients not reported. See data appendix for the sources and definition of the variables.
$-2.19$

$[0.94] * *$

0.36

[0.23]

Yes Yes Yes

Yes Yes Yes

$1,478 \quad 1,478 \quad 1,478$

$\begin{array}{lll}1,478 & 1,478 & 1,478 \\ 0.27 & 0.27 & 0.27\end{array}$

